\title{
The Effect of Direct Democracy on Income Redistribution: Evidence for Switzerland*
}

\author{
by \\ LARS P. FELD ${ }^{\dagger}$ \\ University of Heidelberg, University of St. Gallen (SIAW-HSG), CREMA and CESifo \\ JUSTINA A.V. FISCHER \\ London School of Economics and University of St. Gallen \\ GEBHARD KIRCHGÄSSNER \\ University of St. Gallen (SIAW-HSG), CESifo and Leopoldina
}

$\mathrm{PEPP} / 23$

Political Economy and Public Policy Series

The Suntory Centre

Suntory and Toyota International Centres for

Economics and Related Disciplines

London School of Economics and Political Science

Houghton Street

London WC2A $2 \mathrm{AE}$

October 2006

Tel: (020) 79556674

\begin{abstract}
* Revised Version, October 2006. - We would like to thank John MatsusaKa, THOMAS STRATMAnN and the participants of the Drei-Länder Tagung der deutschen, österreichischen und schweizerischen Vereinigungen für politische Wissenschaft, Bern 2003, the annual conferences of the European Public Choice Society 2004, the Public Choice Society 2004 and the Verein für Socialpolitik 2004 for helpful comments. We also gratefully acknowledge grants from the Swiss National Science Foundation (Grant-No. 5004-58524) as well as the German Science Foundation (DFG SPP 1142).
\end{abstract}

${ }^{\dagger}$ Corresponding author: Prof. Dr. Lars P. Feld, Ruprecht-Karls-University of Heidelberg, Alfred-WeberInstitute, Chair of Public Economics, Grabengasse 14, D-69117 Heidelberg, Germany, e-mail: lars.feld@awi.uni-heidelberg.de 


\begin{abstract}
There is an intensive dispute in political economics about the impact of institutions on income redistribution. While the main focus is on comparison between different forms of representative democracy, the influence of direct democracy on redistribution has attracted much less attention. According to theoretical arguments and previous empirical results, government policies of income redistribution are expected to be more in line with median voter preferences in direct than in representative democracies. In this paper, we find that institutions of direct democracy are associated with lower public spending and revenue, particularly lower welfare spending and broad-based income and property (wealth) tax revenue. Moreover, we estimate a model which explains the determinants of redistribution using panel data provided by the Swiss Federal Tax Office from 1981 to 1997 and a cross section of (representative) individual data from 1992. While our results indicate that less public funds are used to redistribute income and actual redistribution is lower, inequality is not reduced to a lesser extent in direct than in representative democracies for a given initial income distribution. This finding might well indicate the presence of efficiency gains in redistribution policies.
\end{abstract}

JEL-Classification: D7, D78, I30, H75, H11

Keywords: Income Redistribution, Direct Democracy, Referenda, Initiatives.

(c) The authors. All rights reserved. Short sections of text, not to exceed two paragraphs, may be quoted without explicit permission provided that full credit, including $₫$ notice, is given to the source 


\section{Introduction}

In recent analyses in political economics, the impact of constitutional differences between countries on income redistribution has been intensively discussed. Most prominently, PERSSON and TABELLINI (2000) compare majoritarian systems with systems of proportional representation as well as presidential with parliamentarian systems to find out how these institutions affect income redistribution. They argue that majoritarian elections lead to more targeted spending (local public consumption) due to pork barrel politics, less non-targeted spending (broad social spending like unemployment insurance) and a larger size of government (higher taxes) than proportional elections. The reason is not necessarily that proportional elections more strongly reflect the different preferences of citizens in a society, but that majoritarian elections involve more intensive competition for individual districts. Moreover, policy outcomes in presidential systems arguably induce an additional targeting of income redistribution to certain districts. For a panel of OECD countries since the 1960's, MiLESI-FerRETI, PEROTTI and Rostagno (2002) find that transfer payments are indeed strongly positively related to the degree of proportional representation. PERSSON and TABELLINI $(1999,2003)$ support these findings and also report evidence that welfare spending is lower in presidential systems.

In none of these studies, a comparison of direct and representative democracy is undertaken. In this paper, a first attempt is thus made to study the impact of direct democracy on income redistribution using data from Switzerland. There already is an extensive literature on the economic effects of referenda and initiatives (MATSUSAKA 2004, FELD and KIRCHGÄSSNER 2006). According to theoretical arguments and empirical results (POMMEREHNE 1978, STEUNENBERG 1992, GERBER 1999), public policies are more in line with median voter preferences in direct than in representative democracies. Referenda and initiatives provide instruments to selectively control representative and bind policy outcomes to citizens’ preferences (FELD and KIRCHGÄSSNER 2001, BESLEY and COATE 2002). It could thus be expected that income redistribution in direct democracies also differs from that in representative democracies.

The most recent literature dealing with impacts of direct democracy on fiscal policies has mainly focused on expenditure, revenue and debt, which are substantially lowered by referenda or initiatives. This particularly holds for the U.S. states for which MATSUSAKA (2004) provides the most convincing evidence as well as for Swiss cantons (states) and local jurisdictions for which comparable evidence is provided by FELD and KIRCHGÄSSNER (1999, 2001, 2001a) and by FeLD and MATSUSAKA (2003). With respect to the components of public 
spending, Schaltegger (2001) as well as VAtTER and Freitag (2002) find that mainly cantonal and local welfare, culture, police and educational spending, and cantonal administrative spending are reduced by fiscal referenda. FELD and MATSUSAKA (2003a) report that cantons with stronger direct democratic institutions on fiscal issues rely more strongly on user charges than on broad-based taxes to finance spending (see also MATSUSAKA 1995).

The latter results are explained by the argument that direct democracy enforces the benefit principle of taxation according to which public services provided by the government and tax 'prices' levied on citizens should be equivalent. If spending control by the voter is strong, user charges can be more easily justified than broad-based taxes that also affect non-users of a particular public good. Hence, in cantons with strong direct democratic institutions which rely less on taxes but more on fees and user charges as a source of revenue, tax revenue should be lower, and, therefore, less financial means for income redistribution either through the progressive income tax system or welfare payments should be available. Similarly, welfare spending does not necessarily follow from the benefit principle, because its main purpose is to use tax revenue received from progressive income taxation to provide transfer income to the poor such that those paying for welfare do not receive a direct benefit from their payments.

These considerations suggest that direct democratic institutions might reduce income inequality to a lesser extent through the public sector because less public funds are available and allocated for redistribution purposes. However, reducing the size of these funds used does not necessarily lead to a decrease in distributive gaps between the affluent and the needy if redistribution programs are better targeted in direct than in representative democratic systems. It may well be that transfers undertaken in representative democratic systems are much more determined by the rent-seeking activities of interest groups than by the normative goal of providing financial aid to the poor. In direct democratic systems, the stronger control of representatives may simply reduce the transfers provided to special interests and lead to a more effective and more targeted income redistribution from the rich to the poor.

In this study, we first analyse the impact of direct democracy on broad-based taxes and welfare spending. In a second step, we estimate a model to explain the effect of direct democracy on income redistribution using panel data from the Swiss Federal Tax Office, and individual data from the year 1992 provided by LEU ET AL. (1997) and meanwhile part of the Luxembourg Income Study Program. After a brief review of political economy models of income redistribution in Section 2, the empirical studies on institutional determinants of income redistribution are summarised in Section 3. In Section 4, the Swiss institutions of direct democracy 
are introduced. The impact of direct democracy on welfare and taxation is econometrically analyzed in Section 5. The estimation results of the impact of direct democracy on income redistribution are presented in Section 6. Conclusions follow in Section 7.

\section{Political Economy Models of Income Redistribution}

Following the theory of factor rewards, factor supply and demand drive the monetary compensation of labour and capital (abstracting from land) such that each factor is paid its marginal productivity while the exact factor share depends on the elasticity of substitution between factors (CHAMPERNOWNE and COWELL 1998). How factor distribution translates into personal income distribution is a matter of how much each person owns of the different production factors, and of the ability to increase her marginal productivity, e.g., by training. Thus, property rights, the initial endowment with property and ability play an important role.

Starting from such a distribution of primary personal income, income redistribution is undertaken either on a voluntary basis by more affluent individuals or coercively by the state. ${ }^{1)}$ Aside from voluntary income redistribution, the models describing the determinants of coercive income redistribution in a democracy have in common that they mainly built upon the median voter theorem. According to RoMER (1975), RoBerTs (1977) as well as MeLTZER and RICHARD (1981), income redistribution through taxes and transfers is the higher the more skewed the income distribution is. Skewness of the income distribution could be measured by the ratio of mean to median income which provides a good intuition for the political mechanism underlying redistribution: The higher the mean as compared to median income the more the median income taxpayer (supposed to be equivalent to the median voter) can gain from taxing the rich. ${ }^{2)}$ The direction in which income is redistributed, and the resulting net income distribution are, however, not determined., The median voter might form a coalition with the poor in order to exploit the rich (Downs 1957), or a coalition with the rich in order to exploit the poor (POMMEREHNE 1975) such that income redistribution occurs toward the median income position, a finding that is called the Director's Law (STIGLER 1970, TULLOCK 1971, DiXIT and LONDREgAN 1998, BOHN and STUART 2003). The rich might, however, also form a

1. See Kirchgässner and Pommerehne (1992), BoAdway and KeEn (2000) and Harms and Zink (2003) for surveys on income redistribution in democracies.

2. Skewness of the income distribution is however not synonymous to income inequality. See LEE and ROEMER (1998) and BOADWAY and KEEN (2000). For example, two near symmetric income distributions having the same mean but different variances may have the same skewness (close to zero). The less dispersed income distribution could easily be more equal than the other. 
coalition with the poor against the middle income class which has the advantage for the rich of acquiring votes most cheaply. The poor have an incentive to join this coalition because they can expect higher transfers than in a coalition with the middle income class. Such a coalition emerges if the poor realise that they gain relative to a coalition with the middle class. Given the possibility of these different coalitions, no clear-cut predictions on voting outcomes over income redistribution can be made (BOADWAY and KEEN 2000). ${ }^{3)}$

Moreover, the potential emergence of voting cycles prevents any strong prediction on the extent of income redistribution. A general reluctance to redistribute excessively and enter voting cycles may stem from two sources. First, in democracies citizens are more repeatedly involved in income redistribution exercises. This repeated interaction induces co-operative behaviour (EPPLE and RIORDAN 1987, ARTALE and GRÜNER 2000). Citizens simply realise over time that voting cycles on income redistribution lead to nowhere such that a consensus emerges among them according to which only a moderate redistribution takes place. This consensus may be sustained by credible threats to punish those groups in society that deviate from such an implicit 'understanding' (EPPLE and RIORDAN 1987, p. 43, HARMS and ZiNK, 2003, p. 657). Second, tax base effects restrict excessive income redistribution. As already MELTZER and RichaRD (1981) argue, an egalitarian income distribution does not result from tax-transfer-systems decided by the median voter because labour supply incentives are considered. Tax base effects become even more important in open economies when the rich can migrate to jurisdictions with lower redistribution and the poor to those with higher welfare payments (EPPLE and ROMER 1991, PERSSON and TABELLINI 1992). Tax base effects provide for the credibility of threats in repeated interactions of citizens in democracies such that a moderate level of income redistribution can be a stable political outcome.

Since most countries in the world are not constituted as pure direct democracies, the political economy analysis of income redistribution in representative democracies is more relevant than the simple median voter models summarised before. In a citizen candidate model, BESLEY and COATE (1997) analyse electoral competition in a representative democracy. That candidate whose platform attracts a sufficient number of votes wins the race and is able to implement his preferred policy. Although there is an attachment to citizens' preferences through the political/candidate selection process, candidates can follow their own interests between elections. Aside other personal motives of office holders, such interests may also

3. How voter participation affects income redistribution is intensively discussed in the literature without arriving at a clear-cut conclusion. See Frey (1971), Kliemt (1986), BRENNAN and LOMASKY (1993), KirCHGÄSSNER (1992), KIRCHGÄSSNER and POMMEREHNE (1992) or LEE and ROEMER (1998). 
stem from ideological dispositions (DiXIT and LONDREgAN 1998, RoEMER 1998) such that left wing party members impose higher marginal tax rates in progressive income tax schedules than right wing party followers. Second, representatives follow the interests of their constituencies (WEINGAST, SHEPSLE and JOHNSEN 1981). Representatives want to obtain benefits that are geographically concentrated in their electoral district while spreading the costs over the whole population. Logrolling among representatives in parliaments ensures that pork barrel politics remains stable and income redistribution occurs from the districts of the loosing coalition to those of the winning coalition. Third, representatives can be captured by special interest groups that engage in rent seeking activities. ${ }^{4)}$ BESLEY and COATE (1998) show that interest group influence is one source of inefficiency in their citizen candidate model. Rent seeking as such involves redistributing income from those groups in society that are not successfully lobbying the government to those that are. In addition, inefficiencies might occur due to rent dissipation. Finally, representatives might follow the interests of the bureaucracy and redistribute income in their favour (BESLEY and COATE 2003). ${ }^{5)}$ These considerations suggest that, from a societal point of view, in more representative democracies inefficiencies in income redistribution might occur as actual redistribution deviates from the preferred level, and as also those groups might benefit which are not the neediest ones.

Given such a potential deviation of policy outcomes from citizens' preferences, the question arises whether these deviations in income redistribution are different in different constitutional environments. PERSSON and TABELLINI (2000) argue that pork barrel politics are more widespread in majoritarian systems (MAJ) such that they entail more targeted spending (local public consumption), less non-targeted spending (broad social spending like unemployment insurance) and a larger size of government (higher taxes) than systems with proportional representation (PR). The reason is not necessarily that PR systems more strongly reflect the different preferences of citizens in a society, but that majoritarian systems involve stiffer competition for the individual districts. These results are exacerbated if combined with different political regimes. PERSSON and TABELLINI (2000) also study policy outcomes in presidential and parliamentary systems and find that presidential systems reinforce the income redistribution targeted to certain districts. Systems with proportional representation or parliamentary sys-

4. Surveys on rent seeking by interest groups are provided by EKELUND and TOLLISON (2001), MCCHESNEY (2001) and MUELLER (2003).

5. Because the differences in income redistribution between direct and representative democracies is our main interest, we do not review other sources of influence that shape the political economy of income redistribution like e.g. social status or capital market imperfections (see HARMS and ZINK, 2003). We conjecture that the quality of their impact on income redistribution is not determined by the type of democratic systems. 
tems are therefore hypothesised to entail spending projects and taxation that aim at a broad redistribution across the population.

Instead of (or in addition to) enforcing citizens' preferences for income redistribution by electoral competition between representatives or the checks and balances provided in different types of representative democracy, instruments of direct democracy allow for a direct enforcement of citizen preferences. According to theoretical arguments, but also to empirical results (Pommerehne 1978, Gerber 1999, MATSUSAKA 2004), public policies are more in line with median voter preferences in direct than in representative democracies. Referenda and initiatives provide instruments to selectively control representative and correct policy outcomes toward citizens' preferences (FELD and KIRCHGÄSSNER 2001). Due to the particular defects present in a pure representative democracy as described above, it could be expected that income redistribution is exaggerated. Likewise, it can also be expected that income redistribution is less pronounced in direct democracies.

Compared to pure representative democratic systems with majoritarian elections, institutions of direct democracy restrict pork barrel politics and log-rolling. This contention applies either to referenda, in which statutes or constitutional amendments decided in the representative part of the democratic system can be rejected or accepted by the electorate, or popular initiatives, in which citizens formulate legislation directly and are able to induce a decision at the ballots if a pre-specified number of signatures is collected. With respect to referenda, it could be argued that the transaction costs of trading votes in log-rolling exercises are prohibitively high (BRETON 1996). Moreover, as referendum outcomes are in general not attached to outcomes in particular constituencies, citizens consider the general (marginal) cost and (marginal) benefits of a spending project instead of comparing the geographically concentrated (marginal) benefits with nationally dispersed (marginal) cost. REDOANO and SCHARF (2004) and SCHNELLENBACH, FELD and SCHALTEGgER (2006) derive this hypothesis by more formally showing that referenda prevent representatives from centralising government activities via log-rolling. With respect to popular initiatives, BESLEY and COATE (2002) show that initiatives enable citizens to unbundle legislative packages that combine different issues in log-rolling exercises. Unbundling is a possibility to invalidate vote trading that occurred in the past.

Compared to pure representative democratic systems with proportional representation (PR), it is important to emphasise the role of referenda as a possibility to veto policies that are too far away from citizens' preferences. In PR systems, representatives gain a seat in the legislature by entering their party's lists in higher and more promising ranks. In order to get such a posi- 
tion on the party list, past performance of representatives, but also the congruence of that performance with party ideology play a role. Such partisan deviations from citizens' preferences occur less frequently if policies have to pass a referendum. Similar to partisan considerations, partial interests of particular groups could be less easily enforced in systems of direct democracy than in pure PR systems. Popular initiatives enable citizens to question spending projects that entail particular redistributive coalitions.

All in all, as stated above, this might result in direct democracies following the benefit principle of taxation more strongly than pure representative democracies. As income redistribution implies that the marginal benefits from spending projects and the marginal costs of public funds are not equalised for the taxpayer who finances transfers to the needy and vice versa, institutions which promote the benefit principle induce less income redistribution. It should be noted though that systems of social security and welfare also provide an insurance against risks that may not be covered by private markets. Citizens may then be willing to pay for such systems even under a dominance of the benefit principle. In that case, referenda are means to restrict government waste and may induce income redistribution targeted to the needy.

To conclude, our considerations can be summarised in the following hypotheses:

Hypothesis 1: In more direct democratic systems less means are available for the purpose of income redistribution than in pure representative democratic systems.

Hypothesis 2: In more direct democratic systems, income redistribution is less pronounced than in pure representative democratic systems.

On the other hand, the final implications of institutions of direct democracy for the resulting income inequality remain open.

\section{Empirical Studies on Institutional Determinants of Income Redistribution}

From these considerations the prediction results that political institutions matter for income redistribution. Not many empirical studies have, however, been conducted on the impact of institutional determinants of welfare spending and income redistribution. ${ }^{6)}$ There are even not that many which analyse the influence of political economy mechanisms on redistribution

6. An overview of the empirical literature on political democracy and redistribution can be found in GRADSTEIN and MiLANOvic (2000) or GLAESER (2006). 
outcomes. Most empirical studies focus on spending (structure) or revenue (structure), but only a minority on final income distribution measures.

The early studies have been conducted by sociologists and political scientists while economists only recently entered the scene. HEWITT (1977) seems to have been the first to include a measure for the level of democracy as an explanatory variable in his set of determinants in order to analyse the impact of democratic institutions on redistribution. He defines democracy by three purely legalistic characteristics such as the election of the executive, universal suffrage, and the secrecy of ballot. For a cross-section of 25 countries in 1965, he finds that democratic experience had a negative, but insignificant impact on redistribution. However, for the top $5 \%$ or the top $20 \%$ incomes, respectively, the negative impact of democracy on their share of total income was both strong and significant at least at the $10 \%$ level. Thus, the author detects a negative relation between the length of democratic experience and income inequality and hence that more democracy is associated with more income redistribution.

Other studies mainly focus on the institutional determinants of welfare and social security spending. For example, using a panel data set of 18 advanced industrial nations between 1950 and 1980, PAMPEL and WiLLIAMSON (1988) find that both vote per population and electoral competition have a significant positive and robust influence on social welfare spending. The inclusion of state structure (e.g. federalism) does not change the impact of the political variables. Differentiating social welfare in different components, PAMPEL and WILLIAMSON (1988) report a significant positive effect of voting participation on social insurance and family allowances, but an insignificant one on public assistance. Electoral competition proves to be positive and significant only for social insurance and family allowance.

Also LiNDERT (1994) investigates the impact of democracy, proxied by female suffrage, voter turnout and the frequency of executive turnover, on total social transfers and its components, welfare and unemployment, pensions and health expenditure. For a sample of 21 countries covering a long time span from 1880 to 1930 in 10-year-distances he finds a significant positive influence of female suffrage as well as of executive turnover on total social transfers. The latter determinant is also significant and positive for all subcategories of social expenditure. Moreover, voter participation is positive and highly significant for total social transfers, and particularly for pensions and health payments. Again, LINDERT (1994) finds democracy to be associated with higher levels of social transfers. 
More recently, LOTT and KenNy (1999) use panel data on 48 American states from 1870 until 1940. As democracy variables, they consider the existence of a literacy test, a secret ballot, the poll tax, female suffrage, and, finally, the additional turnouts due to female suffrage and the poll tax. The authors argue that (a) the adoption of secret ballot prevented illiterate people and immigrants from voting; and (b) the poll tax, whose payment was a prerequisite for voting, had a disenfranchising effect on blacks and poor whites. Giving women the right to vote obviously increased voter turnout which, in turn, exhibits a positive effect on expenditure of social services, while the literacy test had an insignificant coefficient. The additional turnout reduction due to the poll tax as well as the secret ballot, on the other hand, exhibited significant spending dampening effects. These results show that such institutions, which indicate a lack of democracy, do indeed prevent lower income groups, or, in general, groups favouring redistribution, from voting.

While these previous studies focused on the welfare spending increasing impact of democracy and related indicators, the more recent research conducted by economists analyse its influence conditioned on income equality. For a cross-section of about 50 democratic and non-democratic countries, PEROTTI (1996) applies a 2SLS approach to simultaneously estimate (a) an economic model which describes the effect of fiscal policy on growth, and (b) a political model which comprises democratic institutions and income equality as instruments for the fiscal policy variables. His main result is that the interaction term between the democracy variable and the measure of income equality proved to be negative and significant for social security expenditures which shows that an increase in equality has a negative effect on welfare spending in democracies. PERSSON and TABELLINI (1994) estimate for an international cross-section the impact of the median voter on redistribution, predicting a negative relationship between transfers and the middle quintile, their measure of income equality. Indeed, they find a dampening impact of the middle income share on redistribution, the share of redistributive spending in GDP. In contrast, BASSET et al. (1999), re-estimate this model and do not find the previous result to be robust to differences in definitions of income equality, sample size and the inclusion of the share of senior residents. However, using the average ratio of transfers to GDP over the period 1970-1985, they are able to mildly corroborate a negative relation for democracies using a specification similar to the one in PerotTI (1996). In conclusion, the studies by economists and political scientists suggest that democracy by itself appears to increase means of redistribution, but in case of low income inequality less redistribution occurs, when also the pre-tax income distribution is included in the regression. 
None of these papers has, however, addressed the differential impact of democratic regimes on income redistribution. For a panel of OECD countries since the 1960's, MiLESI-FERRETI, PEROTTI and Rostagno (2002) study whether countries with majoritarian elections have different levels of transfer payments than countries with proportional representation systems and find that transfer payments are strongly positively related to the degree of proportionality. For a panel of 60 countries from 1960 to 1998, Persson and TABELLini $(1999,2003)$ support these findings and also report evidence that welfare spending is lower in presidential systems. Most interestingly, GRADSTEIN et al. (2001) show that parliamentary systems exhibit a higher degree of income redistribution than a pure presidential regime. These results support the hypothesis that the impact of interest groups and bureaucracies on broad-based income redistribution is less restricted in parliamentary systems. With respect to the impact of direct democracy on income redistribution, there is only evidence on the composition of public spending by Schaltegger (2001) and VAtTer and Freitag (2002), who find that mainly welfare spending is reduced by fiscal referenda, and on the composition of revenue by FELD and MATSUSAKA (2003a) who report that cantons with stronger direct democratic institutions on fiscal issues rely more strongly on user charges than on broad-based taxes to finance spending.

\section{Swiss Data on Direct Democracy and the Income Distribution}

Before proceeding to the empirical analysis, it is necessary to briefly introduce the Swiss political system. Switzerland is an ideal laboratory to study the impact of direct democracy on policy outcomes. Aside from its pronounced structure of fiscal federalism, Switzerland is known for its institutions of direct democracy - both at the federal, state and communal levels. All cantons have some form of semi-direct democracy with a parliamentary system with legislators elected according to a system of proportional representation, but the extent of these popular rights varies between cantons (TRECHSEL and SERDÜLT 1999, FELD and MATSUSAKA 2003). Only two rural cantons (Appenzell-Innerrhoden and Glarus) still take political decisions in cantonal meetings (Landsgemeinde), while in the remaining cantons people's will is exercised exclusively through different institutions of political participation at the polls. In all cantons, proposals can be initiated via the voter initiative, and new laws passed by the legislature are, to different degrees, subject to an optional or a mandatory popular referendum. Moreover, fiscal referenda on new spending projects of sub-national governments have been of particular interest in the literature. Finally, the rarely used constitutional initiative and referendum complement the set of institutions of direct legislation. 
Table 1: Fiscal Referenda and Direct Democracy in Swiss Cantons

\begin{tabular}{|c|c|c|c|c|c|}
\hline \multirow{2}{*}{ Canton } & \multicolumn{2}{|c|}{ Non-recurring expenditures ${ }^{a}$} & \multicolumn{2}{|c|}{ Recurring expenditures $^{\mathrm{a}}$} & \multirow{2}{*}{$\begin{array}{c}\text { Frey-Stutzer Index } \\
(1992) \\
\end{array}$} \\
\hline & optional & Mandatory & Optional & mandatory & \\
\hline $\mathrm{ZH}$ & $2-20$ & 20 & $0.2-2$ & 2 & 4.2 \\
\hline $\mathrm{BE}$ & 2 & & 0.4 & & 3.7 \\
\hline LU & $3-25$ & 25 & Specifi & ılations & 4.5 \\
\hline UR & 0.5 & 1 & 0.05 & 0.1 & 5.4 \\
\hline SZ & & 0.25 & & 0.05 & 4.9 \\
\hline OW & 0.5 & 1 & 0.1 & 0.2 & 5.6 \\
\hline NW & 0.25 & 5 & 0.05 & 0.5 & 4.9 \\
\hline GL & & 0.5 & & 0.1 & 5.5 \\
\hline ZG & & 0.5 & & 0.05 & 4.4 \\
\hline FR & $0.25 \%$ & $1 \%$ & $0.25 \%$ & $1 \%$ & 2.5 \\
\hline SO & $1-2$ & 2 & $0.1-0.2$ & 0.2 & 5.7 \\
\hline BS & 1 & & 0.2 & & 4.4 \\
\hline BL & 0.5 & & 0.05 & & 5.7 \\
\hline $\mathrm{SH}$ & $0.3-1$ & 0.3 & $0.05-0.1$ & 0.05 & 5.2 \\
\hline AR & & $5 \%$ & & $1 \%$ & 5.5 \\
\hline AI & 0.25 & 0.5 & 0.05 & 0.1 & 5.3 \\
\hline SG & 3-15 & 15 & $0.3-1.5$ & 1.5 & 3.6 \\
\hline GR & $1-5$ & 5 & $0.3-0.5$ & 0.5 & 4.8 \\
\hline AG & 3 & & 0.3 & & 4.5 \\
\hline TG & 1 & 3 & 0.2 & 0.6 & 4.2 \\
\hline TI & 0.2 & & 0.05 & & 2.1 \\
\hline VD & & & & & 2.4 \\
\hline VS & $0.75 \%$ & & $0.25 \%$ & & 3.4 \\
\hline $\mathrm{NE}$ & & $1.5 \%$ & & $1.5 \%$ & 2.2 \\
\hline GE & 0.125 & & 0.06 & & 1.8 \\
\hline JU & $0.5 \%$ & $5 \%$ & $0.05 \%$ & $0.5 \%$ & 3.7 \\
\hline
\end{tabular}

Source: G. LUTZ and D. STROHMANN (1998); B.S. FREY and A. STUTZER (2000).

$\left.{ }^{a}\right)$ In million Swiss Francs if not indicated otherwise.

b) The index is constructed by the signature requirement as the number of signatures relative to the number of voters, by the days within which the signatures have to be collected and by the financial threshold as the per capita spending limit allowing for referendum (the values correspond to the year 1992).

In our empirical analysis, we use a composite index of direct democracy as proposed by FREY and STUTZER (2000) which consists of many different instruments of direct democracy. ${ }^{7)}$ In order to contrast the index with one of its components, we have a closer look at the data for the fiscal referendum and the index values of the year 1992 (see Table 1). There exists no fiscal referendum at the federal level, but with the exception of the canton of Waadt (VD) all cantons know at least some kind of a fiscal referendum. 13 cantons have a mandatory as well as an optional fiscal referendum. In seven other cantons (BE, BS, BL, AG, TI, VS, GE) only the optional fiscal referendum exists, whereas in SZ, GL, ZG, AR, NE new spending projects have to pass the mandatory, but not an optional fiscal referendum. Comparing the existence of

7. It is constructed as an unweighted average of the indexes of the legislative initiative, the legislative referendum, the constitutional initiative, and the fiscal referendum. 
different forms of fiscal referenda and their spending thresholds with the index of direct democracy, it becomes clear that there is a certain correspondence. On the other hand, it is obvious that the index contains additional information, e.g., based on the signature requirements for the two initiatives and the (optional) statutory referendum. The correlation coefficient between the overall index of direct democracy and a dummy variable for mandatory fiscal referenda is 0.26 , while the signature requirement for the statutory initiative and the direct democracy index is -0.77 . The latter indicates that a higher signature requirement coincides with less direct democracy. ${ }^{8}$ What is also striking are the differences between French and Italian speaking cantons, and German speaking cantons. The average index value of German speaking cantons is with 4.9 almost double as high as that of French and Italian speaking cantons with 2.6.

\section{The Impact of Direct Democracy on Welfare Spending and Taxation}

\subsection{The Model}

In order to test the impact of direct democracy on income redistribution, we follow a two step strategy. First, we analyse public expenditure and revenue as well as tax revenue and welfare spending as the most important instruments for income redistribution at the Swiss cantonal level as a function of the direct democracy index and controls. Second, we analyse income distribution as measured by Gini coefficients of the (approximated) pre- and post tax personal income distribution as well as the difference between both distributions. We thus propose the following basic model:

$$
I D_{i t}=\beta_{0}+\beta_{1} D I R D E M_{i t}+\beta_{2}{ }^{\prime} V_{i t}+u_{i t}
$$

where $I D_{i t}$ stands for the different dependent variables that are of interest for income redistribution. More precisely, in this section we take a closer look at the log of real per capita spending and revenue at the cantonal and local levels as well as tax revenue and welfare spending. In the next section, we analyse Gini coefficients of the pre- and post-tax income distribution.

The model implies that $I D_{i t}$ is a function of direct democracy, as measured by the Frey-Stutzer index $\left(D I R D E M_{i t}\right)$ and a vector of control variables $V_{i t}$. The parameter of interest is $\beta_{1}$, while $u_{i t}$ denotes the error term. In line with previous empirical work by FELD and KIRCHGÄSSNER (1999, 2001, 2001a), FelD and MAtsusaka (2003, 2003a), SCHALtEgGER (2001) as well as

8. The correlation between the signature requirement for the legislative initiative and the spending threshold for the mandatory fiscal referendum is 0.64 suggesting that the strength of popular rights for both institutions tend to coincide. 
VATTER and FrEITAG (2002), and in line with our hypotheses, we expect a negative impact of direct democracy on public spending, revenue, tax revenue and welfare expenditures. The impact of direct democracy on the after-tax income distribution and redistribution is, however, ambiguous. It may well be that, on the one hand, less funds are available for income redistribution, but, on the other hand, transfers are better targeted to the needy. Consequently, the expected sign of the direct democracy index on the Gini coefficients is indeterminate.

$V_{i t}$ consists, first, of variables capturing the structure of fiscal federalism (see the Appendix for descriptive statistics): fiscal decentralisation, measured by the share of local in total subfederal (i.e. cantonal and local) spending (revenue, tax revenue); tax competition, measured by the inverse of the average of all other cantons income tax rates in the highest income tax bracket, weighted by the inverse of geographical distance between cantonal capitals; and unconditional grants which address the impact of vertical transfer payments from the federal government to cantonal governments. The more fiscally decentralised a canton is, the less leeway exists for income redistribution because of migration incentives. Similarly, the intensity of tax competition restricts income redistribution at the sub-federal level. Finally, unconditional grants help to finance additional spending and relax cantonal budget constraints.

Moreover, the log of national income, disaggregated to the cantonal level, is included to capture a possible income effect on the demand for public goods, but also for income redistribution as an insurance against risk. The ratio of urban population in a canton reflects the impact of agglomeration on fiscal policy decisions of governments. In agglomerations, a concentration of poor people often occurs such that additional income redistribution has to be undertaken. On the other hand, the log of population might take into account economies of scale for achieving an identical level of supply of public goods. In addition, a variable incorporating fiscal constraints at the cantonal level is included. They can be seen as a supplementary instrument to limit the spending possibilities of policymakers and hence their ability to redistribute income (SCHALTEGGER, 2002). We also include a coalition variable in order to empirically evaluate the effect of broad-based coalition governments on the exploitation of the budget as a fiscal commons (KontOPOUlos and PEROTTI 1999, VOLKERINK and DE HAAN 2001). Moreover, the net share of conservative parties in the government is considered in order to control for the ideological disposition to redistribute income. In line with the literature, we expect this variable to have a negative impact on (the instruments of) income redistribution. Finally, the share of the young and the share of the senior population are included in order to reveal the influence of the two groups which (supposedly) most strongly benefit from 
income redistribution measures by the state. We also use a French and Italian language dummy to account for cultural differences between Swiss language areas. Finally, year effects are included in the main regression.

The analysis uses annual data from 1980 to 1998 deflated to the year 1980. The subscript $i=$ $1, \ldots, 26$ indicates cantons and $t=1980, \ldots, 1998$ indexes years. The empirical analysis is performed using a pooled cross-section time-series model. As in FELD and KIRCHGÄSSNER (2001), we argue that despite the panel structure of the data the inclusion of fixed effects in the cross-section domain is inappropriate because the institutional variables vary only very little over time in most cantons. Accordingly, cantonal intercepts do not make sense as the captured impact on fiscal outcomes is either solely driven by the time variation or, in case of time invariant variables, fixed effects are likely to hide the impact of institutional variables and render them insignificant. Moreover, OLS estimation with panel-corrected standard errors has the advantage over a random effects method that it yields an efficient estimate with an error variance-covariance estimator robust to three of the common problems associated with panel data: heteroscedasticity across panels, and serial correlation within and across panels. In our case, we employ autocorrelation and heteroscedasticity consistent standard errors according to the Newey West method. ${ }^{9}$ A drawback of the OLS method is, however, that the model specification must be as complete as possible to prevent an omitted variable bias.

The consistency of the estimates equally depends on the exogeneity of the regressands. The direct democracy index is however not instrumented. There is a dispute among Swiss historians and constitutional law scholars whether Swiss direct democracy was created in the middle ages (WILI 1988, BLICKLE 2000) or after the French revolution (KöLZ 1992, 2004, see also AUER 1996 for the discussion). ADLER (2006) takes an intermediate position by arguing that direct "democracy" existed in pre-modern forms in some cantons since the middle ages, but became widespread after the French revolution. While it is possible that direct democracy and the fiscal variables are driven by a third unobserved variable, for example preferences, a true analysis of the endogeneity of direct democracy needs to look very carefully into the history of direct democracy of each Swiss canton separately. Simple strategies to instrument direct democracy are thus not available.

In order to tackle the problem of possible endogeneity of the decentralisation variable in the fiscal policy and redistribution regressions (Tables 2 and 3), we use an instrumental variable

9 In 6 out of the 8 regression models, the null hypothesis of homoscedastic error terms was rejected. 
technique (IV) with the share of Protestants in the census of 1980 and the lagged 4-year growth rate in disaggregated cantonal GDP as exogenous regressors. ${ }^{10)}$ The choice of the first instrument can be justified on historical grounds, while the second captures the effect of a more dynamic economy calling for more flexible, and thus less centralised, policy-making. In the redistribution regressions (Table 3), the ideology of the government is potentially endogenous as redistribution policy influences the median voter's preference for a particular party. We use the cantonal share of foreigners to instrument for government ideology. By construction, also the initial income distribution is endogenous in regression (4) of Table 3. In this case, fragmentation of a canton (number of local communes) and the share of married persons are exogenous variables in the first stage regression. The validity and explanatory power of the instruments is shown through the F-statistics of the excluded instruments in the first stage regression and the J statistics (HANSEN 1982, HANSEN and SINGLETON 1982), which tests the over-identifying restrictions: A non-rejection of the null hypothesis indicates that the instruments are not correlated with the error term of the second stage regression. Since some instruments are weak, we have additionally explored the Anderson-Rubin test of joint significance (DUFOUR 2003). ${ }^{11)}$

\subsection{Results}

Table 2 contains the estimation results for the components of cantonal expenditure and revenue. In all equations, direct democracy has the expected negative sign and is significant at least at the 5 percent level of significance. The coefficient in the public revenue equation (2) is of similar magnitude as the one in the public expenditure equation (1), and the one in the tax revenue equation (3) is slightly bigger in absolute terms. Thus, in cantons with stronger direct democratic institutions less revenue is raised, and accordingly less money is spent. The fact that the tax revenue-lowering impact is (slightly) stronger than the one on overall revenue supports previous findings that direct democratic systems rely less on broad-based redistributive taxes for financing public goods than more representative democratic systems (FELD and MatsusaKa 2003a, MATSUSAKA 1995). The coefficient of direct democracy in the welfare expenditure regression (4) is more than four times larger than those observed in the previous regressions. Direct democracy thus reduces the log of sub-federal welfare spending much more strongly than expenditure or revenue. Moreover, its impact is stronger than that of most

10. An application of a GMM estimator which is efficient in the presence of heteroscedastic and autocorrelated errors did not yield substantially different results form the ones reported here. The small sample size, however, did not permit to rely on this estimator exclusively.

11. Not reported but available from the authors on request. 
of the other fiscal policy variables (budgetary constraints and tax competition), as indicated by the magnitude of its estimated coefficients. These results again corroborate the earlier findings in the literature ${ }^{12)}$ and are in line with the arguments presented above. We conclude that in a direct democracy the government obtains considerably lower funds for redistribution.

In most cases, the remaining controls exhibit expected influences, but also show interesting patterns of results. Fiscal decentralisation is associated with significantly less public spending and revenue, but does not significantly affect tax revenue and welfare spending. Tax competition leads to significantly less public revenue and tax revenue, but it does not significantly impact the two spending measures. As expected, fiscal constraints restrict both general expenditure and also welfare expenditure, and lead to more tax revenue. Hence, balancing the budget comes at the expense of welfare spending. Unconditional grants from the federal level significantly relax the cantonal budget constraints in general and for taxes, but do not significantly influence welfare spending. Among the political variables, the number of parties in the government does not exert any significant effect, except that it weakly increases welfare spending (at the 10\% level). The net share of conservative parties in government is associated with significantly less redistribution in terms of welfare, as expected, but only weakly affects general spending and revenue. On tax revenue, no influence can be observed. Among the economic variables, national income exerts a significant positive impact on all four measures of government activity, but with the statistically weakest effect on public revenue (at the 10 percent level of significance). Hence, the higher income in a canton the higher is tax revenue, an unsurprising result with progressive income tax schedules.

As regards the socio-demographic determinants of fiscal policy, as expected, the degree of urbanisation has a significantly positive impact on welfare expenditure as well as on tax revenue, possibly indicating the concentration of persons in need as well as of affluent households in agglomerations. On general expenditure and revenue, however, no significant impact is observed. Economies of scale, indicated by the negative coefficient on population size, appear to exist only for tax revenue, but not for the remaining public expenditure and revenue measures. The share of young people is significantly associated with lower levels of tax revenue and welfare expenditure, possibly reflecting the fact that they, on the one hand, have not yet entered the labour market, and, on the other hand, still rely on their parents' resources. The share of senior residents has a significantly positive effect on welfare payments, but also on 
total public expenditure as well as revenue. In French and Italian-speaking cantons less welfare spending per capita is observed.

Table 2: Cantonal and Local Expenditure, Revenue, Taxes, and Welfare Expenditure per Capita, 1980 - 1998, 494 Observations

\begin{tabular}{|c|c|c|c|c|}
\hline & $\begin{array}{c}(1) \\
\text { Public } \\
\text { Expenditure }\end{array}$ & $\begin{array}{c}(2) \\
\text { Public } \\
\text { Revenue }\end{array}$ & $\begin{array}{c}(3) \\
\text { Tax } \\
\text { Revenue }\end{array}$ & $\begin{array}{c}(4) \\
\text { Welfare } \\
\text { Expenditure }\end{array}$ \\
\hline Direct democracy & $\begin{array}{c}-0.034 * \\
(2.17)\end{array}$ & $\begin{array}{c}-0.033^{*} \\
(2.34)\end{array}$ & $\begin{array}{c}-0.041^{* * *} \\
(3.33)\end{array}$ & $\begin{array}{l}-0.165^{* * *} \\
\quad(6.89)\end{array}$ \\
\hline Fiscal decentralization & $\begin{array}{c}-1.110^{* * *} \\
(3.74)\end{array}$ & $\begin{array}{c}-0.942^{* * *} \\
(3.47)\end{array}$ & $\begin{array}{l}0.041 \\
(0.21)\end{array}$ & $\begin{array}{l}-0.489 \\
(1.10)\end{array}$ \\
\hline Tax competition & $\begin{array}{l}-0.074 \\
(1.36)\end{array}$ & $\begin{array}{l}-0.107^{*} \\
(2.15)\end{array}$ & $\begin{array}{l}-0.209^{* * *} \\
(7.00)\end{array}$ & $\begin{array}{l}-0.082 \\
(1.01)\end{array}$ \\
\hline Fiscal constraints & $\begin{array}{c}-0.019(*) \\
(1.74)\end{array}$ & $\begin{array}{l}-0.007 \\
(0.75)\end{array}$ & $\begin{array}{l}0.011^{*} \\
(2.06)\end{array}$ & $\begin{array}{c}-0.050^{* * *} \\
(3.51)\end{array}$ \\
\hline Log of unconditional grants & $\begin{array}{c}0.114^{* * * *} \\
(3.52)\end{array}$ & $\begin{array}{c}0.153^{* * *} \\
(4.87)\end{array}$ & $\begin{array}{c}-0.068 * * \\
(2.79)\end{array}$ & $\begin{array}{l}-0.042 \\
(0.83)\end{array}$ \\
\hline $\begin{array}{l}\text { Number of parties } \\
\text { in the cantonal government }\end{array}$ & $\begin{array}{l}0.002 \\
(0.10)\end{array}$ & $\begin{array}{l}0.005 \\
(0.32)\end{array}$ & $\begin{array}{l}-0.002 \\
(0.17)\end{array}$ & $\begin{array}{c}0.042\left(^{*}\right) \\
(1.79)\end{array}$ \\
\hline $\begin{array}{l}\text { Net share of conservative } \\
\text { parties in the government }\end{array}$ & $\begin{array}{c}0.112\left(^{*}\right) \\
(1.72)\end{array}$ & $\begin{array}{c}0.100(*) \\
(1.66)\end{array}$ & $\begin{array}{l}0.037 \\
(1.07)\end{array}$ & $\begin{array}{l}-0.172 * \\
(1.97)\end{array}$ \\
\hline Log of national income & $\begin{array}{l}0.227^{*} \\
(2.04)\end{array}$ & $\begin{array}{c}0.170(*) \\
(1.73)\end{array}$ & $\begin{array}{c}0.350 * * * \\
(5.31)\end{array}$ & $\begin{array}{l}0.305^{*} \\
(2.14)\end{array}$ \\
\hline Urbanization & $\begin{array}{l}0.063 \\
(0.65)\end{array}$ & $\begin{array}{l}0.059 \\
(0.68)\end{array}$ & $\begin{array}{c}0.424 * * * \\
(7.19)\end{array}$ & $\begin{array}{c}0.221(*) \\
(1.73)\end{array}$ \\
\hline Log of population & $\begin{array}{l}0.053 \\
(1.43)\end{array}$ & $\begin{array}{l}0.034 \\
(1.02)\end{array}$ & $\begin{array}{c}-0.041(*) \\
(1.74)\end{array}$ & $\begin{array}{l}-0.023 \\
(0.43)\end{array}$ \\
\hline Share of young population & $\begin{array}{l}0.006 \\
(0.62)\end{array}$ & $\begin{array}{l}-0.004 \\
(0.51)\end{array}$ & $\begin{array}{c}-0.035^{* * *} \\
\quad(6.18)\end{array}$ & $\begin{array}{c}-0.025^{*} \\
(1.98)\end{array}$ \\
\hline Share of old population & $\begin{array}{c}0.021^{* *} \\
(2.78)\end{array}$ & $\begin{array}{l}0.014^{*} \\
(2.25)\end{array}$ & $\begin{array}{l}-0.006 \\
(1.43)\end{array}$ & $\begin{array}{c}0.035^{* * *} \\
\quad(3.41)\end{array}$ \\
\hline $\begin{array}{l}\text { Dummy for French } \\
\text { and Italian language }\end{array}$ & $\begin{array}{l}-0.007 \\
(0.14)\end{array}$ & $\begin{array}{l}-0.057 \\
(1.17)\end{array}$ & $\begin{array}{l}-0.037 \\
(1.03)\end{array}$ & $\begin{array}{c}-0.210 * * \\
(2.61)\end{array}$ \\
\hline Constant & $\begin{array}{c}5.391^{* *} \\
(3.11) \\
\end{array}$ & $\begin{array}{c}5.850 * * \\
(3.92) \\
\end{array}$ & $\begin{array}{l}-1.033 \\
(1.01) \\
\end{array}$ & $\begin{array}{l}4.545^{*} \\
(2.10)\end{array}$ \\
\hline $\begin{array}{l}\text { Observations } \\
\text { Adj. } \mathrm{R}^{2}\end{array}$ & $\begin{array}{c}494 \\
0.6923\end{array}$ & $\begin{array}{c}494 \\
0.7162\end{array}$ & $\begin{array}{c}494 \\
0.9092\end{array}$ & $\begin{array}{c}494 \\
0.8604\end{array}$ \\
\hline F-stat first stage on instr. & $9.52^{* * *}$ & $9.52^{* * *}$ & $9.52^{* * *}$ & $9.52 * * *$ \\
\hline Hansen J stat. & 0.866 & $\begin{array}{l}0.060 \\
4>91\end{array}$ & $4.310^{*}$ & $\begin{array}{l}3.040(*) \\
8040 *\end{array}$ \\
\hline $\begin{array}{l}\text { Notes: Coefficients are estimat } \\
\text { dard errors. The numbers in } \\
\text { '(*)' indicates significance at } \\
\text { mented with the cantonal share }\end{array}$ & $\begin{array}{l}\text { and Newey- } \\
\text { are the abs } \\
1,5 \text {, or } 10 p \\
\text { stants of } 198\end{array}$ & $\begin{array}{l}\text { utocorrelat } \\
\text { alues of th } \\
\text { evels, resp } \\
\text { e lagged } \mathrm{f}\end{array}$ & $\begin{array}{l}\text { heterosceda } \\
\text { ted t-statist } \\
\text { Fiscal dec } \\
\text { growth rate }\end{array}$ & $\begin{array}{l}* \text { onsistent sta } \\
\text { ation is inst } \\
\text { bnal income. }\end{array}$ \\
\hline
\end{tabular}


Generally speaking, the model explains the variation in cantonal spending quite well, as the adjusted $\mathrm{R}^{2} \mathrm{~s}$ of 0.70 and higher indicate. The F-statistics of the excluded instruments show that these are significant predictors of the instrumented variable. The Hansen J statistics cannot reject the null hypothesis, which indicates their validity. The changes in the statistics in the Anderson-Rubin test of joint significance, however, indicate that the instruments perform very well in the first two models (1) and (2), but become weaker in the tax revenue and welfare expenditure regressions in models (3) and (4). The Jarque-Bera test on normality of the residuals rejects the null hypothesis for models (3) and (4). Results with outliers excluded are reported in Table A4 of the Appendix; model (4a) excludes all observations from the bordering canton 'Schaffhausen' while model (4b) excludes the ones of the canton 'Geneva', which is dominated by its well-known capital and has a far-stretched border with France. The estimation outcomes reveal qualitatively the same pattern with respect to direct democracy as already observed in Table 2. In two of three robustness tests of Table A4, the performance of the instruments is enhanced.

\section{The Impact of Direct Democracy on the Redistribution on Income}

\subsection{Synthetic Panel}

As contended above, lower levels of tax revenue and welfare spending do not necessarily imply that less income redistribution is achieved in direct democracies. If direct democracy has a more efficiently working government, these instruments may be more effectively targeted to the needy such that lower funds are necessary to achieve a specific level of income (re)distribution. We therefore turn to the analysis of income distribution and redistribution as measured by Gini coefficients and their difference.

In a first step, we use panel data on the share of taxpaying households and their incomes in different income classes for the period 1980 - 1997 from the Swiss Federal Tax Office that are aggregated at the cantonal level. FLÜCKIGER and ZARIN-NEJADAN (1994) use quite similar data for their analysis of the impact of macroeconomic policy on the income distribution in Switzerland. Since Swiss tax collection until recently has taken place on a biennial basis, the data set is a two years panel. Tax liability for periods $t$ and $t+1$ (taxation period) have been calculated on the basis of the average income of periods $t-1$ and $t-2$ (calculation period). After 1998, the Swiss cantons switched to annual tax collection, though not all at once, so that more recent data is not available yet. This is the reason why the final year used in the panel is 
1997/98. Both pre-tax and post-tax distributions can only be approximated because the FTA data do not cover the true gross or taxable income, but are limited to the 'adjusted gross income' ('Reineinkommen') ${ }^{13)}$ and the actual tax payments. Therefore, we view the 'Reineinkommen' as proxy for gross income and calculate a hypothetical net income by deducing the tax payment. Between cantons there is considerable variation in whether a person is entitled to financial support and how big the size of the actual transfer is. Some of these social transfers directly affect the gross income and the adjusted gross income, some impact only the after-tax income of the needy households. ${ }^{14)}$

The estimation method and the basic model to be estimated is the one described in Section 5 . However, income distribution might have an impact on voting behaviour and, therefore, also on the ideological position of the government. For this reason, as described before, the ideology of the government is instrumented with the share of foreign residents in Swiss cantons. For reasons given in Section 5, the fiscal decentralisation variables is viewed as potentially endogenous and the identical set of economic and socio-demographic instruments as in the expenditure regressions is applied.

The estimation results are presented in Table 3. The first column contains the results for the pre-tax Gini coefficient (in percentage points). The direct democracy index has a negative impact on the pre-tax Gini coefficient which is highly significant at the $0.1 \%$ level. Consequently, in cantons with a higher degree of direct democracy, income distribution before the governments begin to redistribute income via taxes and further allowances is more equal. ${ }^{15)}$ Fiscal decentralisation does not appear to affect the pre-tax income distribution, while tax competition is weakly associated with a more unequal distribution of income (at the 10 percent level). In contrast, fiscal constraints exert a significant inequality lowering impact on the pre-tax income distribution. The two political determinants 'size of coalition in the cantonal government' and 'ideology of government' are not decisive for the pre-tax income distribution. Among the economic determinants, higher national income is associated with more pronounced inequality, while federal transfers prove not influential. In contrast to expectations, urbanisation and population density are not associated with a particular income distribution. A larger share of older persons is related to a more equal income distribution, which might re-

13. For a more precise definition and description of the relation between gross income, 'Reineinkommen' and taxable income according to the Swiss laws of taxation, see HÖHN and WALDBURGER, 2001, p. 359.

14. We thank E. LAUBER, tax inspector of the ESTV/FTA for clarification (personal speech, June 1, 2004).

15. As stated above, this observed impact may be possibly induced by welfare payments at the sub-federal level which already affect the adjusted gross income of Swiss households. 
flect the highly redistributive nature of the Swiss pension system. Income distribution does not appear to be affected by the ratio of young residents, but a more equal income distribution is observed in cantons with French or Italian speaking cantons.

The regression outcomes for the income distribution measured by post-tax Gini coefficient shows the same qualitative pattern of results (column (2) of Table 3): With respect to our variable of interest, cantons with more direct democracy have also more equal post-tax income distributions (at the 0.1 percent level). For the remaining determinants we observe similar impacts on the post-tax income distribution as already detected for the pre-tax distribution.

It is most interesting to look at the difference between pre- and post-tax income distributions which indicates to what extent the closing of the gap in income inequality is due to the different variables in our model. Note that a positive (negative) sign in the difference equation in columns (3) and (4) means that a variable has a positive (negative) impact on the size of income redistribution, i.e. more (less) income is redistributed. A positive (negative) impact also implies that redistribution is more (less) equalising because the direction of redistribution in all cantons is inequality decreasing. ${ }^{16)}$ The estimation results in column (3) reveal that significantly less income redistribution occurs in direct democratic cantons (at the $0.1 \%$ level). The remaining variables show the same pattern of results as before in models (1) and (2). There is significantly less effective income redistribution in cantons with stronger fiscal constraints, with a higher share of senior residents, and in the French and Italian speaking cantons. On the other hand, wealthier cantons engage more in redistribution activities (at the 5\% level).

It is most interesting to finally analyse the impact of the different variables on income redistribution conditioned on the pre-tax income distribution as reported in the fourth column of Table $3 .^{17)}$ This method allows identification of those variables that affect income redistribution when it may be most needed to close the gap between the rich and the poor. As expected, a high pre-tax income inequality triggers more redistribution (significance at the 0.1 percent level). Again, the effect of direct democracy is very instructive: Conditioned on the pre-tax income distribution, cantons with direct democracy do exhibit nearly the same amount of income redistribution as cantons with a more representative political system. ${ }^{18)}$

16. For all cantons in all years, post-tax income distribution minus pre-tax distribution has a negative sign.

17. In addition to the instruments mentioned above we employ the cantonal shares of married persons and a measure of cantonal fragmentation.

18. The inclusion of an interaction term between direct democracy and the initial income distribution did not change our estimation results. Both interaction term and political institution were (jointly) insignificant. 
Table 3: Inequality and Redistribution, 1981 - 1997, 208 Observations

(Gini-Coefficients in Percentage Points)

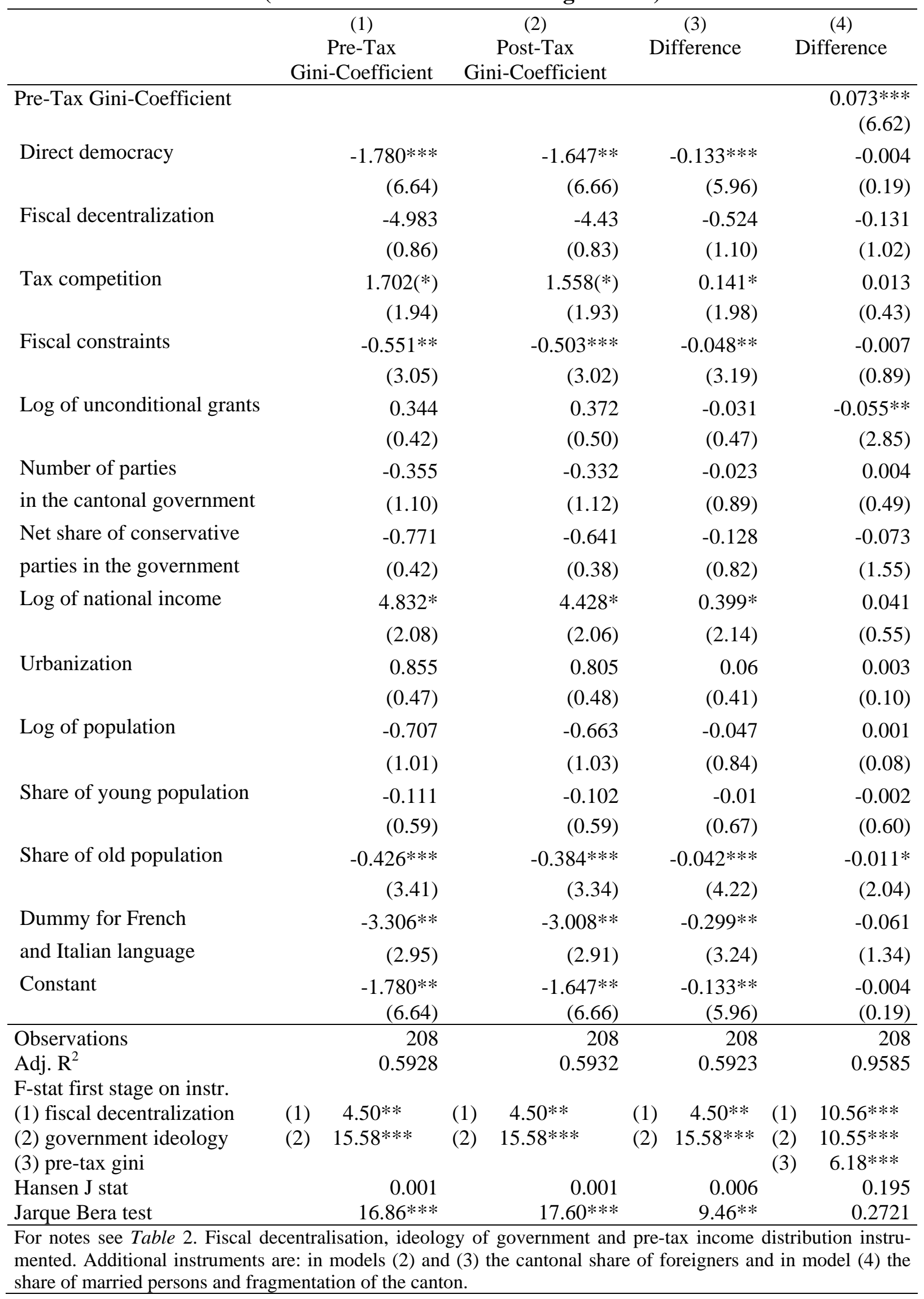


In column (4), most of the political and economic determinants prove insignificant, as their effect might be captured by the initial pre-tax income distribution, for which only weak instruments were available. ${ }^{19)}$ Transfers from the federal government are, however, associated with less effective redistribution, as is the cantonal share of retired persons (at the 1 and 5 percent levels, respectively). Overall, the model explains the variation in income distribution and redistribution quite well: At least $60 \%$ of the variance can be explained. The F-statistics on the excluded instruments show that the instruments are quite weak for fiscal decentralisation in models (1) through (3), and equally for the pre-tax income distribution in model (4), while this does not apply to the ideology of government in all models. They do, however, fail to reject the Hansen $J$ test of over-identification. The rejection of the null hypothesis of the Jarque Bera test in models (1) through (3) might indicate the presence of potentially influential outliers. Estimation results when outliers are excluded (Table A5 of the Appendix) reveal no qualitative changes for the inequality- and redistribution-decreasing impact of direct democracy. Moreover, in models (1) through (3), the impact of the political institutions appears now slightly more sizeable. Changes in significance levels in the control variables are observed for unconditional federal transfers, which are now weakly associated with more income inequality (models (1) and (2)), and the size of the canton in terms of population, revealing an income distribution equalising impact (models (1) and (2)). Finally, in model (3) exclusion of outliers does not change the impact of any determinant of effective income redistribution. In Table A5, the performance of the instruments is enhanced as indicated by the substantially higher F-value on the excluded instruments in the first stage regression, particularly in models (1) and (2). Given that instruments are weak for fiscal decentralisation for the complete data set, the estimation results in this robustness check are of particular importance.

Taking the results of Tables 2 and 3 together, the impact of direct democracy is very intriguing: There are significantly less funds in terms of tax revenue and transfers available for income redistribution, and there is evidently less effective equalisation of income inequality. But if the pre-tax income inequality is taken into account, income redistribution in direct democratic cantons is as high as in all other cantons. This supports the hypothesis that welfare payments and tax exemptions in direct democratic cantons are better targeted than in more representative cantons: the available means are more effectively used in direct than in representative democratic cantons.

19. According to StAiger and StOCK (1997), rule o thumb is a F-value on the excluded instruments of 10. 


\subsection{Individual Data}

In a second step, we explain income (re-)distribution by using a representative cross-section of individual data collected in 1992 by LEU, BuRri and PRIESTER (1997) for the study "Quality of Life and Poverty in Switzerland", which have been matched with official tax statements of the main taxpayer for each interviewed household. On the one hand, using this data remedies the measurement problem in the Swiss tax administration data with respect to gross income and after tax income; on the other hand, new problems arise as this cross-section of 1992 allows only variation of cantonal characteristics between cantons, but not across time.

Exploiting the individual data structure, we estimate the following equation

$$
I D_{i t}=\beta_{0}+\beta_{1} \operatorname{DIRDEM}_{i t}+\beta_{2}{ }^{\prime} V_{i t}+\beta_{3}{ }^{\prime} Z_{i t}+u_{i t}
$$

where $t=1992$. In addition to the variables at the cantonal level already employed in the previous panel regressions $\left(V_{i t}\right)$, we include a vector of individual characteristics of the taxpayer $\left(Z_{i t}\right)$ which might constitute important determinants of income and tax payments. These characteristics include age group, citizenship, occupational status, civil status and family type, education, and the type and size of the community of the interviewee. The dependent variable is the equivalent household income of all household members (1) before, and (2) after cantonal and communal tax payments, and (3) the difference between them. ${ }^{20)}$ As in the analysis at the cantonal level, we analyse the extent of redistribution conditioning on predicted household gross income to prevent an endogeneity bias, employing additional exogenous regressors as instruments. ${ }^{21)}$ Using a quantile regression technique, we estimate this model for the $10^{\text {th }}$, $20^{\text {th }}, 30^{\text {th }}, 50^{\text {th }}, 70^{\text {th }}, 80^{\text {th }}$ and $90^{\text {th }}$ quantiles with a sample of 4178 observations. ${ }^{22)}$

Table 4 displays the estimated coefficients and the significance levels of the direct democracy variables for the various quantiles of the conditional income distribution. ${ }^{23)}$ With the gross equivalent household income as dependent variable (column 1), the degree of direct democracy does not exert any significant impact on any of the estimated quantiles. This impression

20. Unfortunately, the LEU-data do not allow to distinguish the income of the main taxpayer from the income of his or her partner, so that the individual income cannot be determined.

21. We employ the number of adult persons, a dummy for receiving welfare payments, and the education of the respondent as instruments. Estimating an IV regression, all instruments pass the usual tests of validity, power and orthogonality.

22. Students, oversampled elderly persons and persons with missing tax data have been deleted from the originally 6000 observations. DORN ET AL. (2005) provide evidence that using the weighted full sample generates unreliable results and the unweighted representative, albeit the smaller sample is to be preferred.

23. The full set of the quantile regressions can be found in the Appendix Tables A6 to A10. 
is confirmed by the F-test on the joint significance of the coefficients of direct democracy, which fails to reject the null that their impact equals zero. In addition, we found no significant differential impact of direct democracy between the various quantiles. Hence, the inequality lowering impact of direct democracy detected in the synthetic panel (Table 3 column (1)) is not corroborated with these more precise individual income tax data.

Table 4: Inequality and Redistribution, 1992, 4178 Observations

\begin{tabular}{|c|c|c|c|c|c|}
\hline & (1) & (2) & (3) & (4a) & (4b) \\
\hline & $\begin{array}{l}\text { Pre-Tax } \\
\text { Household } \\
\text { Income }\end{array}$ & $\begin{array}{l}\text { Post-Tax } \\
\text { Household } \\
\text { Income }\end{array}$ & Difference & $\begin{array}{c}\text { Difference } \\
\text { (predicted gross } \\
\text { income) }\end{array}$ & $\begin{array}{c}\text { Difference } \\
\text { (original } \\
\text { gross income) }\end{array}$ \\
\hline $10^{\text {th }}$ quantile & $\begin{array}{c}-511.451 \\
(0.39)\end{array}$ & $\begin{array}{c}-881.204 \\
(0.65)\end{array}$ & $\begin{array}{c}-293.799 * \\
(2.55)\end{array}$ & $\begin{array}{c}-324.958 * * \\
(2.84)\end{array}$ & $\begin{array}{c}-309.271^{* * *} \\
(2.65)\end{array}$ \\
\hline $20^{\text {th }}$ quantile & $\begin{array}{c}-1108.593 \\
(0.97)\end{array}$ & $\begin{array}{c}-898.465 \\
(0.91)\end{array}$ & $\begin{array}{c}-309.411^{* *} \\
(2.62)\end{array}$ & $\begin{array}{c}-272.174 * \\
(2.27)\end{array}$ & $\begin{array}{c}-382.801^{* * *} \\
(3.64)\end{array}$ \\
\hline $30^{\text {th }}$ quantile & $\begin{array}{c}-2179.545 \\
(1.57)\end{array}$ & $\begin{array}{c}-1449.298 \\
(0.62)\end{array}$ & $\begin{array}{c}-358.607 * * \\
(2.76)\end{array}$ & $\begin{array}{c}-284.219 * \\
(2.24)\end{array}$ & $\begin{array}{c}-393.587 * * * \\
(4.35)\end{array}$ \\
\hline $50^{\text {th }}$ quantile & $\begin{array}{c}-1857.755 \\
(0.86)\end{array}$ & $\begin{array}{c}-1645.376 \\
(1.20)\end{array}$ & $\begin{array}{l}-405.208^{*} \\
(2.42)\end{array}$ & $\begin{array}{c}-108.648 \\
(0.58)\end{array}$ & $\begin{array}{c}-251.039 \\
(0.55)\end{array}$ \\
\hline $70^{\text {th }}$ quantile & $\begin{array}{c}-2156.702 \\
(0.38)\end{array}$ & $\begin{array}{c}-941.291 \\
(0.25)\end{array}$ & $\begin{array}{c}-645.401^{* *} \\
(2.68)\end{array}$ & $\begin{array}{c}-308.565 \\
(1.35)\end{array}$ & $\begin{array}{c}-182.899 \\
(0.88)\end{array}$ \\
\hline $80^{\text {th }}$ quantile & $\begin{array}{c}-3609.568 \\
(0.81)\end{array}$ & $\begin{array}{c}-1599.494 \\
(0.08)\end{array}$ & $\begin{array}{c}-904.024 * * * \\
(3.19)\end{array}$ & $\begin{array}{c}-564.656^{*} \\
(2.52)\end{array}$ & $\begin{array}{c}-129.624 \\
(0.79)\end{array}$ \\
\hline $90^{\text {th }}$ quantile & $\begin{array}{c}-3355.007 \\
(0.87)\end{array}$ & $\begin{array}{c}-1311.208 \\
(0.44)\end{array}$ & $\begin{array}{c}-1129.295 * \\
(2.47)\end{array}$ & $\begin{array}{c}-727.442 \\
(1.50)\end{array}$ & $\begin{array}{c}-23.910 \\
(0.13)\end{array}$ \\
\hline Observations & 4178 & 4178 & 4178 & 4175 & 4178 \\
\hline $\begin{array}{l}\text { Pseudo R-squared } \\
\left(50^{\text {th }} \text { quantile) }\right. \\
\text { F-test (direct democ- } \\
\text { racy in all estimated }\end{array}$ & 0.1956 & 0.1974 & 0.1454 & 0.1532 & 0.5117 \\
\hline quantiles) & $\begin{array}{l}0.50 \\
\text { None }\end{array}$ & $\begin{array}{l}0.27 \\
\text { None }\end{array}$ & $\begin{array}{c}2.44^{*} \\
\mathrm{q} 10-\mathrm{q} 80^{*} \\
\mathrm{q} 10-\mathrm{q} 90\left(^{*}\right)\end{array}$ & $\begin{array}{c}1.70 \\
\mathrm{q} 50-\mathrm{q} 80^{*}\end{array}$ & $\begin{array}{c}3.02^{* *} \\
\mathrm{q} 20-\mathrm{q} 90\left({ }^{*}\right) \\
\mathrm{q} 30-\mathrm{q} 90(*)\end{array}$ \\
\hline $\begin{array}{l}\text { Significant differ- } \\
\text { ences of institutional } \\
\text { impact between } \\
\text { quantiles }\end{array}$ & & & $\begin{array}{c}\mathrm{q} 20-\mathrm{q} 80^{*} \\
\left.\mathrm{q} 20-\mathrm{q} 90 *^{*}\right) \\
\mathrm{q} 30-\mathrm{q} 80^{*} \\
\mathrm{q} 30-\mathrm{q} 90\left(^{*}\right) \\
\mathrm{q} 50-\mathrm{q} 80\left(^{*}\right)\end{array}$ & & \\
\hline
\end{tabular}

\footnotetext{
Notes: 1000 replications. Regressors include the determinants at the cantonal level of sections 5 and 6, and taxpayer specific information such as gender, being a foreigner, type of household, age groups, number of adults, tertiary education, occupational status and type of employment, owning a house, capital, being in military service, receiving sick payments, size and type of community of household, living in an urbanised area. Regression (4a) and (4b) also include the gross equivalent household income as explanatory variable. In (4a), its values have been predicted using as instruments the number of adult persons in the household, a dummy indicating whether the taxpayer receives welfare transfers, and the level of education of the interviewee, who is not always the taxpayer. In an IV estimation for the average redistribution, these instrument proved to be valid (Hansen J Statistics $=2.146$ ) and passed the weak instrument test $($ F-test on excl. instr. $=35.10)$. In addition, each instrument satisfied the orthogonality condition.
} 
Looking at the regression outcome for net income (column 2), we observe, however, no significant impact of direct democracy on net income either, which we defined as gross income minus the communal and cantonal tax payments. The test of joint significance and the test of differential institutional impact corroborate this result. On the one hand, this finding might be interpreted as contradicting the respective aggregate analysis, which showed an inequality lowering impact (Table 3 column (2)). On the other hand, these quantile regressions analyse the institutional influence conditional on wage and tax determining individual characteristics, so that it might well understate an actual impact on the unconditional distribution.

In columns (3) and (4) the dependent variable is the volume of income reduction through communal and cantonal tax payments as measured by the difference between gross and net income. ${ }^{24)}$ In these regressions, a negative (positive) coefficient indicates that more (less) money remains in people's pockets. For all estimated quantiles, we find a significantly negative impact of direct democracy. This result indicates that in more direct democratic cantons people's income is reduced to a lesser extent through local and cantonal taxes than in more representative political systems. This finding corresponds to the result of a tax revenue lowering influence of direct democracy in the aggregate analysis (Table 2 column (3)). The magnitude varies substantially between the quantiles, with a one-point increase in the democracy index equalling lower tax reductions of about 300 up to 1100 Swiss Francs. ${ }^{25)}$ Differential impacts of political institutions appear to be present particularly between the lowest two and the highest two quantiles, which indicates that the absolute reduction in taxes is larger for higher household incomes than for smaller incomes. This result is not surprising given progressive income tax schedules. But it also indicates that less income redistribution occurs in direct democratic systems than in representative democratic systems because the income reductions due to redistributive taxation are overall larger in representative democratic cantons than the respective income reductions in direct democratic cantons. In addition, this effect is more pronounced in absolute terms in the upper end of the income distribution than in the lower end which indicates less effective income redistribution in direct democracies.

24. It should be noted that, in contrast to the least squares regressions, column (3) does not exactly correspond to the difference between columns (1) and (2) because the quantile regression method derives the density function by ordering observations according to their value of the dependent variable. The observations, e.g., in the $10^{\text {th }}$ quantile in the first regression are thus not the same as in the $10^{\text {th }}$ quantile of the second regression.

25. Only persons with tax records are contained in these data. Thus, persons with an income below the minimum taxable income are not included. Gross income comprises welfare transfers and subsidies, which positively contributes to the taxable income. 
In regression (4a) we include the predicted gross income as additional control, analogously to the inclusion of the initial income distribution in the synthetic panel (Table 3, column 4). Given the initial amount of gross equivalent household income, for the lower three quantiles the tax payment reducing impact persists though to a quantitatively lesser extent. Thus, a onepoint increase in direct democracy appears associated with a tax relief of about 300 Swiss France for persons in the lower part of the income distribution. This result contrasts the one obtained for the synthetic panel (Table 2 column (4)), as it suggests that (conditional) income might be more equally distributed in more direct democratic cantons, even if gross income is controlled for. This interpretation, in turn, supports the view that in direct democracy tax schemes are more effectively targeted towards unburdening the needy. A significantly more reduced tax burden is equally found for the $80^{\text {th }}$ quantile, possibly increasing income inequality. In addition, a test of equality of coefficients, however, cannot reject the null of equal size for differences between the lowest three and the highest quantile. In contrast, the estimate on the $80^{\text {th }}$ quantile, however, is significantly different from the one in the $50^{\text {th }}$ quantile.

In column (4b) we present estimation results when the initial gross income is not instrumented. Again, we find a significant tax payment lowering effect of direct democracy in the first three quantiles, but no impact on the $80^{\text {th }}$ quantile. Also, a differential institutional impact is present between some lower and the highest quantile, which supports the difference in tax reduction between these quantiles. These results are in favour of an equalising impact of direct democracy on the distribution of net income, a result we have observed using aggregate panel data (Table 3). Again, this outcome supports the view that in direct democracies tax schemes are more effectively targeted towards unburdening the less affluent.

\section{Concluding Remarks}

Does direct democracy lead to less redistribution? Taking into account that it leads to lower welfare expenditure and less tax revenue per capita, one might draw such a conclusion. Such an apprehension is probably behind the strong rejection of introducing additional direct popular rights in Germany by some political scientists: They fear the end of the welfare state. The possible effects might be largely overestimated by such fears; despite the well developed direct popular rights the Swiss welfare state has not yet broken down, and a cutback of public welfare expenditure occurred in purely representative systems like the German one during recent years as well. Nevertheless, there might be - ceteris paribus - a negative impact of direct democracy on redistribution. That public welfare expenditure is somewhat lower might, 
on the other hand, not necessarily compromise redistribution. Because public expenditure might be better tailored to the needs of the electorate in direct democracies, given the amount of public welfare expenditure its redistributive effect might be larger than in purely representative systems. Taking these two countervailing effects into account, it is theoretically open which of them dominates.

Our results provide an interesting picture. Looking just at the differences between the income distributions before and after taxation, it is shown that direct democracy has a negative impact on redistribution, as it is supposed by many of its critics. But taking into account that redistribution is needed the more unequal the pre-tax income distribution is, direct democracy looses its negative effect on redistribution completely. Using household level tax data, tax savings occur in more direct democratic cantons which are favouring smaller incomes even when taking into account the initial household gross income. Moreover, analysing its impact on the pre-tax and after-tax income distributions a strong inequality equalising effect of direct legislation could be revealed. This indicates two things: first, efficiency gains are present in direct democracies when it comes to reducing income inequality; second, redistribution is the more effective the more the electorate assesses it as being justified by unequal starting conditions. Such behaviour will rather strengthen than weaken the welfare state.

The results which are presented in this paper provide, however, only for a first step. Further analyses have to follow. One obvious shortcoming of this study is that by using tax data those who do not pay taxes (and might be the poorest citizens in the society) are not included in our analysis. Another shortcoming of these tax data are that they are rather based on household than personal income and do not take into account the number of persons living in the same household. Finally, one should take into account that we only deal with the cantonal and local level and, there, mainly with the tax side, which is, of course, very important for redistribution. Nevertheless, a large part of redistribution is done by public expenditure. ${ }^{26)}$ Moreover, the perhaps strongest redistributive part of the Swiss welfare state is the first pillar of the old age pension system (AHV) which is assigned to the federal level. It is much more redistributive as, e.g., the corresponding German pension system. Nevertheless, not only its introduction but also all of its revisions have finally been accepted in nationwide popular referenda. Thus, Switzerland with its direct democracy at all governmental levels can hardly be seen as an example where the welfare state is endangered by the existence of direct popular rights. 


\section{References}

ADLER, B. (2006), Die Entstehung der direkten Demokratie: Das Beispiel der Landsgemeinde Schwyz 1789 - 1866, NZZ Verlag, Zürich.

ARTALE, A., and H.-P. GRÜNER (2000), A Model of Stability and Persistence in a Democracy, Games and Economic Behavior 33 (2000), pp. 20-40.

Auer, A. (ed.) (1996), Les origines des la démocratie directe en Suisse, Helbing and Lichtenhahn, Genève.

BASSET, W.F., J.P. BURKETT and L. PUTTERMAN (1999), Income Distribution, Government Transfers, and the Problem of Unequal Influence, European Journal of Political Economy 15 (1999), pp. 207-228.

Besley, T., and S. CoATE (1997), An Economic Model of Representative Democracy. Quarterly Journal of Economics 112, pp. 85-114.

Besley, T., and S. COATE (1998), Sources of Inefficiency in a Representative Democracy: A Dynamic Analysis. American Economic Review 88, pp. 139-156.

Besley, T., and S. COATE (2002), Issue Unbundling via Citizens' Initiatives, mimeo, London School of Economics.

BESLEY, T., and S. COATE (2003), Elected vs. Appointed Regulators: Theory and Evidence, Journal of the European Economic Association 1 (2003), pp. 1176-1206.

BLICKLE, P. (2000), Kommunalismus: Skizzen einer gesellschaftlichen Organisationsform, München.

BoAdwAy, R., and M. KeEN (2000), Redistribution, in: A.B. AtKInSON and F. BoURGUIGNON (eds.), Handbook of income Distribution Vol 1., Elsevier, Amsterdam, pp. 677-789.

Bohn, H., and C. STUART (2003), Voting and Nonlinear Taxes in a Stylized Representative Democracy, CESifo Working Paper No. 1058, Munich.

Brennan, G., and L. Lomasky (1993), Democracy and Decision: The Pure Theory of Electoral Preference, Cambridge University Press, Cambridge.

Breton, A. (1996), Competitive Governments: An Economic Theory of Politics and Public Finance, Cambridge University Press, Cambridge.

Champernowne, D.G., and F.A. Cowell (1998), Economic Inequality and Income Distribution, Cambridge University Press, Cambridge.

Dixit, A., and J. LONDREgAN (1998), Ideology, Tactics, and Efficiency in Redistributive Politics, Quarterly Journal of Economics 113 (1998), pp. 497-529.

DorN, D., J.A.V. FISCHER, G. KIRCHGÄSSNER and A. SOUSA-POZA, (2005), Is It Culture or Democracy? The Impact of Democracy, Income, and Culture on Happiness, University of St. Gallen Department of Economics working paper series, 2005-12.

Downs, A. (1957), An Economic Theory of Democracy, Harper and Row, New York.

Dufour, J.-M. (2003), Identification, Weak Instruments, and Statistical Inference in Econometrics, Canadian Journal of Economics, (2003), v. 36 (4), pp. 767-808

EKELUND, R.B., and R.D. TOLLISON (2001), The Interest-Group Theory of Government, in: W.F. ShUGART II and L. RAzzolini (eds.), The Elgar Companion to Public Choice, Edward Elgar, Cheltenham, pp. 357-378.

EPPLE, D., and M.H. RIORDAN (1987), Cooperation and Punishment under Repeated Majority Voting, Public Choice 55 (1987), pp. 41-73.

EPPLE, D., and T. ROMER (1991), Mobility and Redistribution, Journal of Political Economy 99 (1991), pp. 828-858. 
FELD, L.P. (2000), Steuerwettbewerb und seine Auswirkungen auf Allokation und Distribution: Ein Überblick und eine empirische Analyse für die Schweiz, Mohr (Siebeck), Tübingen.

FELD, L.P., and G. KIRCHGÄSSNER (1999), Public Debt and Budgetary Procedures: Top Down or Bottom up? Some Evidence from Swiss Municipalities, in: J.M. POTERBA and J. VON HAGEN (eds.), Fiscal Institutions and Fiscal Performance, Chicago University Press, Chicago, pp. 151-179.

FELD, L.P., and G. KIRCHGÄSSNER (2001), The Political Economy of Direct Legislation: Direct Democracy in Local and Regional Decision-Making, Economic Policy 33 (2001), pp. 329-367.

FeLD, L.P., and G. KIRCHGÄssNer (2001a), Does Direct Democracy Reduce Public Debt? Evidence from Swiss Municipalities, Public Choice 109 (2001), pp. 347-370.

FELD, L.P., and G. KIRCHGÄSSNER (2006), Fiscal Policy and Direct Democracy: Institutional Design Determines Outcomes, in: A.F. OTT and R.J. Cebula (eds.), The Elgar Companion to Public Economics: Empirical Public Economics, Edward Elgar, Cheltenham 2006, S. 215 - 241

FELD, L.P., and J.G. MATSUSAKA (2003), Budget Referendums and Government Spending: Evidence from Swiss Cantons, Journal of Public Economics 87 (2003), pp. 2703-2724.

FELD, L.P., and J.G. MATSUSAKA (2003a), The Political Economy of Tax Structure: Some Panel Evidence for Swiss Cantons, mimeo, University of St. Gallen.

Feld, L.P., C. SchaltegGer and J. SChNellenbach (2006), On Government Centralization and Fiscal Referendums, Unpublished Manuscript, University of Marburg 2006.

FLÜCKIGER, Y., and M. ZARIN-NEJADAN (1994), The Effect of Macroeconomic Variables on the Distribution of Income. The Case of Switzerland, Journal of Income Distribution 4 (1994), pp. 2539.

FREY, B.S. (1971), Why Do High Income People Participate More in Politics?, Public Choice 11 (1971), pp. $101-105$.

FREY, B.S., and A. STUTZER (2000), Happiness, Economy and Institutions, Economic Journal 110 (2000), pp. 918-938.

GERBER E.R. (1999), The Populist Paradox: Interest Group Influence and the Promise of Direct Legislation, Princeton University Press, Princeton.

GLAESER, E.L. (2006), Inequality, forthcoming in: B.R. WEINGAST and D. WITTMAN (eds.), The Oxford Handbook of Political Economy, Oxford University Press, Oxford.

Gradstein, M. and B. Milanovic, (2004), Does Liberté = Egalité? A Survey of the Empirical Evidence on the Links between Political Democracy and Income Inequality with Some Evidence on the Transition Economies, Journal of Economic Surveys, 18 (2004), pp. 515 - 537.

GradSTEIN, M., B. MilanOVIC and Y. YING (2001), Democracy and Income Inequality: An Empirical Analysis, Policy Research Working Paper No. 2561, March 2001.

HANSEN, L.P. (1982) Large Sample Properties of Generalized Method of Moments Estimators, Econometrica 50, pp. 1029-1054.

HANSEN, L.P., and K. J. SINGLETON (1982), Generalized Instrumental Variables Estimation of Nonlinear Rational Expectations Models, Econometrica 50, pp. 1269-1286.

HARMS, P., and S. ZINK (2003), Limits to Redistribution in a Democracy: A Survey, European Journal of Political Economy 19 (2003), pp. 651-668.

HEwITT, C. (1977), The Effect of Political Democracy and Social Democracy on Equality in Industrial Societies: A Cross-National Comparison, American Sociological Review 42 (1977), pp. 450464.

HÖHN, E., and R. WALDBURGER (2001), Steuerrecht Band 1, Schriftenreihe Finanzwirtschaft und Finanzrecht, $9^{\text {th }}$ revised and extended edition, Haupt, Bern et al.. 
KIRCHGÄssneR, G. (1992), Towards a Theory of Low-Cost Decisions, European Journal of Political Economy 8 (1992), pp. 305-320.

KIrChGÄssner, G., and W.W. Pommerehne (1992), Approaches to Explain Fiscal Redistribution in Democracy, mimeo, University of Saarland, Saarbrücken.

KIrChGÄssneR, G., and W.W. Pommerehne (1996), Tax Harmonization and Tax Competition in the European Union: Lessons from Switzerland, Journal of Public Economics 60, S. 351 - 371.

KLIEMT, H. (1986), The Veil of Insignificance, European Journal of Political Economy 2, pp. 333 344.

KÖLZ, A. (1992), Neuere Schweizerische Verfassungsgeschichte: Ihre Grundlinien vom Ende der alten Eidgenossenschaft bis 1848, Stämpfli, Bern.

KÖLZ, A. (2004), Neuere Schweizerische Verfassungsgeschichte: Ihre Grundlinien in Bund und Kantonen seit 1848, Stämpfli, Bern.

Kontopoulos, Y., and R. Perotti (1999), Government Fragmentation and Fiscal Policy Outcomes: Evidence from OECD Countries, in: J.M. POTERBA and J. vON HAGEN (eds.), Fiscal Institutions and Fiscal Performance, Chicago University Press, Chicago, pp. 81-102.

LeE, W., and J.E. RoEmer (1998), Income Distribution, Redistributive Politics, and Economic Growth, Journal of Economic Growth 3 (1998), pp. 217-240.

LeU, R.E., ST. BuRRI and T. PRIESTER (1997), Lebensqualität und Armut in der Schweiz, Haupt, Bern.

LindeRT, P.H. (1994), The Rise of Social Spending, 1880 - 1930, Explorations in Economic History 31 (1994), pp. 1-37.

LoTT, J.R., and L.W. KENNY (1999), Did Women's Suffrage Change the Size and Scope of Government? Journal of Political Economy 107 (1999), pp. 1163-1198.

LUTZ G., and D. STROHMANN (1998), Wahl- und Abstimmungsrecht in den Kantonen, Haupt, Bern.

MAtsusAKA, J.G. (1995), Fiscal Effects of the Voter Initiative: Evidence from the Last 30 Years, Journal of Political Economy 103 (1995), pp. 587-623.

MAtsusaKA, J.G. (2004), For the Many or the Few: How the Initiative Process Changes American Government, University of Chicago Press, Chicago.

MCCHESNEY, F.S. (2001), Rent-Seeking and Rent Extraction, in: W.F. SHUGART II and L. RAZzOLINI (eds.), The Elgar Companion to Public Choice, Edward Elgar, Cheltenham, pp. 379-395.

MeltZer, A., and S. Richard (1981), A Rational Theory of the Size of Government, Journal of Economy 89 (1981), pp. 914-927.

Milesi-Ferreti, G.-M., R. Perotti and M. Rostagno (2002), Electoral Systems and the Composition of Public Spending, Quarterly Journal of Economics 117 (2002), pp. 609-657.

MuelLeR, D.C. (2003), Public Choice III, Cambridge University Press, Cambridge.

PAMPEL, F.C., and J.B. WiLLIAMSON (1988), Welfare Spending in Advanced Industrial Democracies, 1950-1980, American Sociological Review 93 (1988), pp. 1424-1456.

Perotti, R. (1996), Growth, Income Distribution and Democracy: What the Data Say, Journal of Economic Growth 1 (1996), pp. 149-187.

Persson, T., and G. TABellini (1992), The Politics of 1992: Fiscal Policy and European Integration, Review of Economic Studies 59 (1992), pp. 689-701.

Persson, T., and G. TABellini (1994), Is Inequality Harmful for Growth, American Economic Review 84 (1994), pp. 600-621.

Persson, T., and G. TABellini (1999), The Size and Scope of Government: Comparative Politics with Rational Politicians, European Economic Review 43 (1999), pp. 699-735. 
Persson, T., and G. TABellini (2000), Political Economics: Explaining Economic Policy, MIT Press, Cambridge.

Persson, T., and G. TABellini (2003), The Economic Effects of Constitutions: What Do the Data Say?, MIT Press, Cambridge.

POMMEREHNE, W.W. (1975), Öffentliche Güter und öffentliche Ausgaben in der direkten Demokratie. Dissertation, University of Konstanz.

Pommerehne, W.W. (1978), Institutional Approaches to Public Expenditure: Empirical Evidence from Swiss Municipalities, Journal of Public Economics 9 (1978), pp. 255-280.

RedoAno, M., and K.A. Scharf (2004), The Political Economy of Policy Centralization: Direct Versus Representative Democracy, Journal of Public Economics 88 (2004), pp. 799-817.

RoBerts K. (1977), Voting over Income Tax Schedules, Journal of Public Economics 8 (1977), pp. 329-340.

Roemer, J.E. (1998), Why the Poor Do Not Expropriate the Rich: An Old Argument in New Garb, Journal of Public Economics 70 (1998), pp. 399-424.

Romer, T. (1975), Individual Welfare, Majority Voting and the Properties of a Linear Income Tax, Journal of Public Economics 7 (1975), pp. 163-168.

Schaltegger, CH. (2001), The Effects of Federalism and Democracy on the Size of Government: Evidence from Swiss Sub-national Jurisdictions, ifo Studien 47 (2001), pp. 145-162.

SCHALTEGgER, C. (2002), Budgetregeln und ihre Wirkung auf die öffentlichen Haushalte: Empirische Ergebnisse aus den US-Bundesstaaten und den Schweizer Kantonen, Schmollers Jahrbuch 122 (2002), pp. 369-413.

SChNelLenbach, J., L.P. Feld and C. SchaltegGer (2006), The Impact of Referendums on the Centralisation of Public Goods Provision: A Political Economy Approach, Unpublished Manuscript, University of Marburg 2006.

STAIGER, D., and J.H. STOCK (1997), Instrumental Variables Regression With Weak Instruments, Econometrica 65 (1997), pp. 557-586.

Steunenberg, B. (1992), Referendum, Initiative and Veto Power: Budgetary Decision-Making in Local Government, Kyklos 45 (1992), pp. 501-529.

Stigler, G.J. (1970), Director's Law of Public Income Distribution, Journal of Law and Economics 13 (1970), pp. 1-10.

TRECHSEL, A., and U. SERDÜLT, (1999), Kaleidoskop Volksrechte: Die Institutionen der direkten Demokratie in den schweizerischen Kantonen (1970-1996), Helbing and Lichtenhahn, Basel.

TUllock, G. (1971), The Charity of the Uncharitable, Western Economic Journal 9 (1971), pp. 379-392.

VATTER, A., and M. FreitAG (2002), Die Janusköpfigkeit von Verhandlungsdemokratien: Zur Wirkung von Konkordanz, direkter Demokratie und dezentraler Entscheidungsstrukturen auf den öffentlichen Sektor der Schweizer Kantone, Swiss Political Science Review 8 (2002), pp. 53-80.

VOLKERINK B., and J. DE HAAN (2001), Fragmented Government Effects on Fiscal Policy: New Evidence, Public Choice 109 (2001), 221-242.

Weingast, B.R., K. SHEPSLE and C. JOHNSEN (1981), The Political Economy of Benefits and Costs: A Neoclassical Approach to Distributive Politics, Journal of Political Economy 89 (1981), pp. 642-664.

WILI, H.-U. (1988), Kollektive Mitwirkungsrechte von Gliedstaaten in der Schweiz und im Ausland, Stämpfli, Bern. 


\section{Appendix}

Table A1: Descriptive Statistics for Cantonal Budget Sample, 494 observations

\begin{tabular}{lrrrr}
\hline \multicolumn{1}{c}{ Variable } & \multicolumn{1}{c}{ Mean } & \multicolumn{1}{c}{ Std. Dev. } & \multicolumn{1}{c}{ Min } & Max \\
\hline Public expenditure p.c. & 10581.28 & 2610.31 & 6801.75 & 19221.50 \\
Log of public expenditure. & 9.24 & 0.23 & 8.82 & 9.86 \\
Public revenue p.c. & 10344.57 & 2363.41 & 6766.88 & 18922.76 \\
Log of public revenue & 9.22 & 0.21 & 8.82 & 9.85 \\
Tax revenue p.c. & 3.24 & 1.01 & 1.83 & 7.34 \\
Log of tax revenue & 1.14 & 0.27 & 0.60 & 1.99 \\
Welfare Expenditure p.c. & 694.45 & 368.93 & 218.09 & 2226.95 \\
Log of welfare expenditure & 6.42 & 0.48 & 5.38 & 7.71 \\
Direct democracy & 4.29 & 1.22 & 1.50 & 5.83 \\
Fiscal decentralization & 0.33 & 0.11 & -0.01 & 0.49 \\
Tax competition & -1.50 & 0.37 & -2.30 & -0.87 \\
Fiscal constraints & 0.37 & 1.08 & 0.00 & 4.00 \\
Log of unconditional grants & 6.07 & 0.33 & 5.41 & 7.18 \\
Number of parties & & & & \\
in the cantonal government & 3.25 & 0.86 & 1.00 & 5.00 \\
Net share of conservative & & & & \\
parties in the government & -0.10 & 0.18 & -0.60 & 0.40 \\
Log of national income & 10.68 & 0.20 & 10.32 & 11.44 \\
Urbanization & 0.31 & 0.24 & 0.00 & 0.99 \\
Log of population & 11.93 & 1.11 & 9.45 & 13.99 \\
Share of young population & 27.23 & 3.59 & 17.33 & 35.70 \\
Share of old population & 19.26 & 2.44 & 13.70 & 27.07 \\
Dummy for French & & & & \\
or Italian language & 0.27 & 0.44 & 0.00 & 1.00 \\
\hline
\end{tabular}


Table A2: Descriptive Statistics for Tax Data Regression Sample, 208 observations

\begin{tabular}{lrrrr}
\hline \multicolumn{1}{c}{ Variable } & Mean & \multicolumn{1}{c}{ Std. Dev. } & \multicolumn{1}{c}{ Min } & Max \\
\hline Pre-tax Gini coefficient & 30.18 & 2.53 & 24.12 & 39.49 \\
Post-tax Gini coefficient & 29.13 & 2.34 & 23.53 & 37.81 \\
Difference in Gini coefficients & 1.05 & 0.21 & 0.57 & 1.68 \\
Direct democracy & 4.30 & 1.22 & 1.50 & 5.83 \\
Fiscal decentralization & 0.33 & 0.11 & -0.01 & 0.49 \\
Tax competition & -1.50 & 0.37 & -2.30 & -0.87 \\
Fiscal constraints & 0.37 & 1.08 & 0.00 & 4.00 \\
Log of unconditional grants & 6.05 & 0.32 & 5.45 & 7.13 \\
Number of parties & & & & \\
in the cantonal government & 3.26 & 0.86 & 1.00 & 5.00 \\
Net share of conservative & & & & \\
parties in the government & -0.10 & 0.18 & -0.60 & 0.40 \\
Log of national income & 10.68 & .20 & 10.33 & 11.40 \\
Urbanization & 0.31 & 0.24 & 0.00 & 0.99 \\
Log of population & 11.92 & 1.11 & 9.46 & 13.98 \\
Share of young population & 27.22 & 3.53 & 17.39 & 35.08 \\
Share of old population & 19.26 & 2.44 & 13.90 & 26.95 \\
$\begin{array}{l}\text { Dummy for French or } \\
\text { Italian language }\end{array}$ & & & & \\
\hline $\begin{array}{l}\text { Note: Values of the explanatory variables are two-year averages, following the biannual structure of } \\
\text { the Tax data on which the Gini coefficients are based. }\end{array}$ & & & \\
\hline
\end{tabular}


Table A3: Descriptive Statistics for Quantile Regressions, Leu Data 1992, 4174 observations

\begin{tabular}{|c|c|c|c|c|}
\hline Variable & Mean & Std. Dev. & Min & Max \\
\hline Pre-tax income & 46362.92 & 39955.31 & 0 & 1443500 \\
\hline Post-tax / Post-transfer income & 42515.63 & 34483.88 & 0 & 1214301 \\
\hline Income difference & 3847.29 & 6425.32 & 0 & 229199.30 \\
\hline Predicted pre-tax income & 46370.13 & 18089.43 & 2039.42 & 116477.20 \\
\hline Direct Democracy & 4.01 & 0.99 & 1.75 & 5.69 \\
\hline Number of parties in the cantonal government & 3.67 & 0.80 & 1 & 5 \\
\hline Log of population & 12.97 & 0.85 & 9.59 & 13.96 \\
\hline Fiscal constraints & 0.36 & 0.94 & 0 & 3 \\
\hline Fiscal decentralization & 0.38 & 0.09 & 0.02 & 0.47 \\
\hline Tax competition & -1.45 & 0.29 & -2.32 & -0.95 \\
\hline Log of unconditional grants & 5.88 & 0.19 & 5.62 & 6.78 \\
\hline Net share of conservative parties in the government & -0.09 & 0.17 & -0.60 & 0.40 \\
\hline Urbanization & 65.87 & 19.85 & 14.34 & 100 \\
\hline Share of young population & 24.93 & 2.35 & 17.51 & 31.14 \\
\hline Share of old population & 19.15 & 1.85 & 15.45 & 26.30 \\
\hline Log of national income & 3.64 & 0.17 & 3.31 & 4.18 \\
\hline Dummy for French or Italian language & 0.19 & 0.39 & 0 & 1 \\
\hline Swiss /permanent resident & 0.23 & 0.42 & 0 & 1 \\
\hline Cohabiting & 0.96 & 0.20 & 0 & 1 \\
\hline Married & 0.32 & 0.47 & 0 & 1 \\
\hline Married with kids & 0.60 & 0.49 & 0 & 1 \\
\hline Single & 0.34 & 0.47 & 0 & 1 \\
\hline Single parent & 0.17 & 0.38 & 0 & 1 \\
\hline Age $30-39$ & 0.02 & 0.15 & 0 & 1 \\
\hline Age $40-49$ & 0.22 & 0.41 & 0 & 1 \\
\hline Age $50-59$ & 0.19 & 0.39 & 0 & 1 \\
\hline Age 60 - 69 & 0.13 & 0.34 & 0 & 1 \\
\hline Age $>70$ & 0.11 & 0.32 & 0 & 1 \\
\hline Swiss /permanent resident & 0.17 & 0.38 & 0 & 1 \\
\hline Tertiary education of taxpayer & 0.09 & 0.29 & 0 & 1 \\
\hline Tertiary education of taxpayer's partner & 0.02 & 0.13 & 0 & 1 \\
\hline Retired & 0.29 & 0.45 & 0 & 1 \\
\hline Unemployed & 0.03 & 0.18 & 0 & 1 \\
\hline Self-employed & 0.10 & 0.30 & 0 & 1 \\
\hline Household located in city & 0.63 & 0.48 & 0 & 1 \\
\hline House owner & 0.31 & 0.46 & 0 & 1 \\
\hline Other capital income $>0$ & 0.78 & 0.42 & 0 & 1 \\
\hline Bauer & 0.04 & 0.20 & 0 & 1 \\
\hline Farmer & 0.01 & 0.09 & 0 & 1 \\
\hline Income compensation due to military service & 0.01 & 0.10 & 0 & 1 \\
\hline Income compensation due to illness/accident & 0.20 & 0.40 & 0 & 1 \\
\hline Community size 2 & 0.16 & 0.37 & 0 & 1 \\
\hline Community size 3 & 0.25 & 0.43 & 0 & 1 \\
\hline Community size 4 & 0.07 & 0.25 & 0 & 1 \\
\hline Community size 5 & 0.12 & 0.32 & 0 & 1 \\
\hline Community size 6 & 0.25 & 0.43 & 0 & 1 \\
\hline Community type 2 & 0.13 & 0.33 & 0 & 1 \\
\hline Community type 3 & 0.07 & 0.26 & 0 & 1 \\
\hline Community type 4 & 0.13 & 0.33 & 0 & 1 \\
\hline Community type 5 & 0.08 & 0.28 & 0 & 1 \\
\hline Community type 6 & 0.02 & 0.15 & 0 & 1 \\
\hline Community type 7 & 0.02 & 0.13 & 0 & 1 \\
\hline
\end{tabular}


Table A4: Cantonal and Local Expenditure, Revenue, Taxes, and Welfare Expenditure per Capita, 1980 - 1998, 494 Observations, Outliers excluded

\begin{tabular}{|c|c|c|c|}
\hline & $\begin{array}{c}\text { (3) } \\
\text { Tax } \\
\text { Revenue }\end{array}$ & $\begin{array}{c}(4 a) \\
\text { Welfare } \\
\text { Expenditure }\end{array}$ & $\begin{array}{c}(4 \mathrm{~b}) \\
\text { Welfare } \\
\text { Expenditure }\end{array}$ \\
\hline Direct democracy & $\begin{array}{c}-0.042^{* * *} \\
(3.46)\end{array}$ & $\begin{array}{c}-0.160 * * * \\
(5.18)\end{array}$ & $\begin{array}{c}-0.095^{* * *} \\
(4.11)\end{array}$ \\
\hline Fiscal decentralization & $\begin{array}{l}-0.002 \\
(0.01)\end{array}$ & $\begin{array}{c}-1.550\left(^{*}\right) \\
(1.83)\end{array}$ & $\begin{array}{c}-0.752(*) \\
(1.88)\end{array}$ \\
\hline Tax competition & $\begin{array}{c}-0.208 * * * \\
(7.13)\end{array}$ & $\begin{array}{l}0.131 \\
(0.99)\end{array}$ & $\begin{array}{l}0.117 \\
(1.61)\end{array}$ \\
\hline Fiscal constraints & $\begin{array}{c}0.010(*) \\
(1.93)\end{array}$ & $\begin{array}{l}-0.081^{* * *} \\
\quad(3.50)\end{array}$ & $\begin{array}{c}-0.056^{* * *} \\
(4.03)\end{array}$ \\
\hline Log of unconditional grants & $\begin{array}{c}-0.070 * * \\
(2.89)\end{array}$ & $\begin{array}{c}0.05 \\
(0.75)\end{array}$ & $\begin{array}{l}0.039 \\
(0.75)\end{array}$ \\
\hline $\begin{array}{l}\text { Number of parties } \\
\text { in the cantonal government }\end{array}$ & $\begin{array}{r}-0.001 \\
(0.12)\end{array}$ & $\begin{array}{l}0.025 \\
(0.80)\end{array}$ & $\begin{array}{l}0.006 \\
(0.26)\end{array}$ \\
\hline $\begin{array}{l}\text { Net share of conservative parties } \\
\text { in government }\end{array}$ & $\begin{array}{c}0.03 \\
(0.90)\end{array}$ & $\begin{array}{l}-0.009 \\
(0.08)\end{array}$ & $\begin{array}{l}-0.086 \\
(0.97)\end{array}$ \\
\hline Log of national income & $\begin{array}{c}0.344^{* * *} \\
(5.33)\end{array}$ & $\begin{array}{l}0.398 * \\
(2.07)\end{array}$ & $\begin{array}{c}0.438 * * \\
(3.36)\end{array}$ \\
\hline Urbanization & $\begin{array}{c}0.418^{* * *} \\
(7.22)\end{array}$ & $\begin{array}{l}0.161 \\
(0.97)\end{array}$ & $\begin{array}{l}-0.064 \\
(0.61)\end{array}$ \\
\hline Log of population & $\begin{array}{c}-0.040\left(^{*}\right) \\
(1.71)\end{array}$ & $\begin{array}{l}0.111 \\
(1.09)\end{array}$ & $\begin{array}{l}0.088^{*} \\
(2.01)\end{array}$ \\
\hline Share of young population & $\begin{array}{c}-0.035^{* * *} \\
(6.34)\end{array}$ & $\begin{array}{l}0.012 \\
(0.50)\end{array}$ & $\begin{array}{l}-0.01 \\
(0.84)\end{array}$ \\
\hline Share of old population & $\begin{array}{c}-0.007(*) \\
(1.68)\end{array}$ & $\begin{array}{c}0.046^{* * *} \\
(3.22)\end{array}$ & $\begin{array}{c}0.063^{* * *} \\
(7.25)\end{array}$ \\
\hline $\begin{array}{l}\text { Dummy for French } \\
\text { and Italian language }\end{array}$ & $\begin{array}{l}-0.042 \\
(1.22)\end{array}$ & $\begin{array}{l}-0.078 \\
(0.71)\end{array}$ & $\begin{array}{l}-0.022 \\
(0.28)\end{array}$ \\
\hline Constant & $\begin{array}{l}-0.941 \\
(0.95) \\
\end{array}$ & $\begin{array}{l}0.741 \\
(0.21) \\
\end{array}$ & $\begin{array}{l}0.614 \\
(0.32) \\
\end{array}$ \\
\hline Observations & 492 & 475 & 475 \\
\hline Adj. $R^{2}$ & 0.9140 & 0.8160 & 0.8467 \\
\hline F-stat first stage on instruments & 9.61 & 3.82 & 10.48 \\
\hline Hansen J stat. & $4.383 *$ & 2.481 & 0.821 \\
\hline Jarque Bera test & 3.921 & 3.876 & $4.644(*)$ \\
\hline
\end{tabular}

For notes see Table 2 
Table A5: Inequality and Redistribution, 1981 - 1997, 208 Observations, Outliers excluded

\begin{tabular}{|c|c|c|c|}
\hline & $\begin{array}{c}(1) \\
\text { Pre-Tax } \\
\text { Gini-Coefficient }\end{array}$ & $\begin{array}{c}(2) \\
\text { Post-Tax } \\
\text { Gini-Coefficient }\end{array}$ & $\begin{array}{c}(3) \\
\text { Difference }\end{array}$ \\
\hline Direct democracy & $\begin{array}{c}-1.872^{* * *} \\
(10.32)\end{array}$ & $\begin{array}{c}-1.733 * * * \\
(10.35)\end{array}$ & $\begin{array}{c}-0.136 * * * \\
(8.30)\end{array}$ \\
\hline Fiscal decentralization & $\begin{array}{l}-2.786 \\
(0.72)\end{array}$ & $\begin{array}{l}-2.387 \\
(0.67)\end{array}$ & $\begin{array}{l}-0.467 \\
(1.30)\end{array}$ \\
\hline Tax competition & $\begin{array}{c}1.154(*) \\
(1.84)\end{array}$ & $\begin{array}{c}1.047\left(^{*}\right) \\
(1.81)\end{array}$ & $\begin{array}{l}0.135^{*} \\
(2.44)\end{array}$ \\
\hline Fiscal constraints & $\begin{array}{c}-0.510^{* * *} \\
(4.24)\end{array}$ & $\begin{array}{c}-0.465^{* * *} \\
(4.21)\end{array}$ & $\begin{array}{c}-0.046^{* * *} \\
(4.11)\end{array}$ \\
\hline Log of unconditional grants & $\begin{array}{c}0.898\left(^{*}\right) \\
(1.72)\end{array}$ & $\begin{array}{c}0.891(*) \\
(1.86)\end{array}$ & $\begin{array}{l}-0.024 \\
(0.48)\end{array}$ \\
\hline $\begin{array}{l}\text { Number of parties } \\
\text { in the cantonal government }\end{array}$ & $\begin{array}{l}-0.129 \\
(0.61)\end{array}$ & $\begin{array}{l}-0.12 \\
(0.62)\end{array}$ & $\begin{array}{l}-0.021 \\
(1.10)\end{array}$ \\
\hline $\begin{array}{l}\text { Net share of conservative } \\
\text { parties in the government }\end{array}$ & $\begin{array}{l}-1.199 \\
(0.93)\end{array}$ & $\begin{array}{l}-1.041 \\
(0.88)\end{array}$ & $\begin{array}{l}-0.125 \\
(1.06)\end{array}$ \\
\hline Log of national income & $\begin{array}{c}4.232^{* *} \\
(2.70)\end{array}$ & $\begin{array}{c}3.872 * * \\
(2.68)\end{array}$ & $\begin{array}{c}0.370 * * \\
(2.66)\end{array}$ \\
\hline Urbanization & $\begin{array}{l}0.491 \\
(0.40)\end{array}$ & $\begin{array}{l}0.462 \\
(0.41)\end{array}$ & $\begin{array}{l}0.064 \\
(0.59)\end{array}$ \\
\hline Log of population & $\begin{array}{c}-0.976^{*} \\
(2.13)\end{array}$ & $\begin{array}{c}-0.913^{*} \\
(2.16)\end{array}$ & $\begin{array}{l}-0.056 \\
(1.34)\end{array}$ \\
\hline Share of young population & $\begin{array}{l}-0.193 \\
(1.58)\end{array}$ & $\begin{array}{l}-0.177 \\
(1.58)\end{array}$ & $\begin{array}{l}-0.014 \\
(1.27)\end{array}$ \\
\hline Share of old population & $\begin{array}{c}-0.452 * * * \\
(5.55)\end{array}$ & $\begin{array}{c}-0.408^{* * *} \\
(5.43)\end{array}$ & $\begin{array}{c}-0.044 * * * \\
(6.02)\end{array}$ \\
\hline $\begin{array}{l}\text { Dummy for French } \\
\text { and Italian language }\end{array}$ & $\begin{array}{c}-4.000 * * * \\
(5.37)\end{array}$ & $\begin{array}{c}-3.655^{* * *} \\
(5.32)\end{array}$ & $\begin{array}{c}-0.310 * * * \\
(4.46)\end{array}$ \\
\hline Constant & $\begin{array}{l}17.507 \\
(0.78) \\
\end{array}$ & $\begin{array}{c}17.276 \\
(0.84) \\
\end{array}$ & $\begin{array}{c}0.17 \\
(0.09)\end{array}$ \\
\hline $\begin{array}{l}\text { Observations } \\
\text { Adj. } \mathrm{R}^{2}\end{array}$ & $\begin{array}{c}203 \\
0.6866\end{array}$ & $\begin{array}{c}203 \\
0.6877\end{array}$ & $\begin{array}{c}206 \\
0.6372\end{array}$ \\
\hline $\begin{array}{l}\text { F-stat first stage on instruments } \\
\text { (1) fiscal decentralization } \\
\text { (2) government ideology } \\
\text { Hansen J stat. } \\
\text { Jarque Bera test }\end{array}$ & $\begin{array}{ll}\text { (1) } & 8.28^{* * *} \\
\text { (2) } & 22.81^{* * *} \\
& 1.287 \\
& 3.924 \\
\end{array}$ & $\begin{array}{ll}\text { (1) } & 8.28^{* * *} \\
\text { (2) } & 22.81^{* * *} \\
& 1.306 \\
& 3.382 \\
\end{array}$ & $\begin{array}{ll}\text { (1) } & 6.97^{* * *} \\
\text { (2) } & 23.05^{* * *} \\
& 0.264 \\
& 4.148 \\
\end{array}$ \\
\hline
\end{tabular}

For notes see Table 3 
Table A6: Quantile Regressions for Pre-Tax Household Income, 4178 Observations

\begin{tabular}{|c|c|c|c|c|c|c|c|}
\hline & $10^{\text {th }}$ quantile & $20^{\text {th }}$ quantile & $30^{\text {th }}$ quantile & $50^{\text {th }}$ quantile & $70^{\text {th }}$ quantile & $80^{\text {th }}$ quantile & $90^{\text {th }}$ quantile \\
\hline Direct Democracy & -511.451 & -1108.593 & -2179.545 & -1857.755 & -2156.702 & -3609.568 & -3355.007 \\
\hline Number of parties in cantonal government & 1074.704 & -335.592 & -216.121 & -428.353 & -142.817 & -1707.710 & -1250.739 \\
\hline Log of population & 110.895 & -61.440 & -3.007 & 489.522 & -83.886 & -538.763 & -1082.783 \\
\hline Fiscal constraints & -107.006 & -560.143 & -1009.735 & $-1726.121(*)$ & -1148.014 & -1849.433 & -1382.850 \\
\hline Fiscal decentralization & 1002.692 & 605.125 & -1350.504 & -6997.795 & -4270.456 & 695.248 & 1536.364 \\
\hline Tax competition & 3016.027 & 1932.991 & 1057.027 & 6108.909 & 6475.081 & 7870.502 & 9381.777 \\
\hline Log of unconditional grants & -2327.454 & -8039.990 & -8576.728 & -8588.309 & -7729.974 & -16142.480 & -14851.610 \\
\hline Net share of conservative parties in government & -4387.638 & -6926.316 & $-10356.160 *$ & -4482.195 & -4086.703 & -7567.873 & -2551.745 \\
\hline Urbanization & 9.839 & -119.728 & $-193.269(*)$ & -114.449 & -75.077 & -287.432 & -331.602 \\
\hline Share of young population & 464.077 & -138.584 & -681.555 & 160.422 & 863.457 & 361.487 & -1323.315 \\
\hline Share of old population & 261.562 & 179.101 & -211.075 & 131.039 & 646.360 & 707.101 & -689.671 \\
\hline Log of national income & -1501.243 & 11639.220 & 12617.160 & 17435.870 & 23044.490 & 45917.880 & 45382.860 \\
\hline Dummy for French or Italian language & -2748.302 & -2284.370 & -5761.270 & -736.818 & -2130.847 & -1117.497 & 1252.002 \\
\hline Female & 1338.032 & 989.198 & -64.759 & -1717.990 & $-6079.401(*)$ & $-7674.407^{* * *}$ & $-10023.350 * *$ \\
\hline Swiss /permanent resident & 1610.187 & 2010.821 & 2177.131 & -2053.822 & -487.381 & -1281.857 & -2222.340 \\
\hline Cohabiting & $11825.570 * * *$ & $10725.050 * * *$ & $10182.370 * * *$ & $7536.451 * * *$ & $5272.207(*)$ & 4435.089 & 1242.939 \\
\hline Married & $-4287.784 * *$ & $-3703.653 *$ & $-5048.760 * *$ & $-6422.738 * *$ & $-8382.142(*)$ & $-9057.120 * *$ & $-9729.051 *$ \\
\hline Married with kids & $4612.596 *$ & -365.469 & -3297.833 & $-9942.715^{* * *}$ & $-15265.650 * * *$ & $-16878.420 * * *$ & $-22803.220 * * *$ \\
\hline Single & $2398.283(*)$ & $2814.294 *$ & 1413.149 & -128.350 & -1235.237 & -1715.907 & -3514.244 \\
\hline Single parent & $-12948.110 * * *$ & $-17226.070^{* * *}$ & $-13841.090 * * *$ & $-16450.480 * * *$ & $-17372.550 * * *$ & $-17389.740 * * *$ & $-19262.670 * * *$ \\
\hline Age 30 - 39 & 1161.489 & 828.921 & 444.537 & 2338.961 & 4017.438 & 4227.392* & 6336.388* \\
\hline Age 40 - 49 & 1559.419 & 1793.271 & 1809.966 & $3722.859 *$ & 6198.502 & $8395.236 * * *$ & $12318.060 * * *$ \\
\hline Age $50-59$ & 317.778 & -261.709 & -1032.165 & 1399.870 & 5428.913 & 8204.299** & $7854.344 *$ \\
\hline Age 60 - 69 & $-3440.555(*)$ & $-4940.386 * *$ & $-5603.759 * *$ & -3826.657 & 183.411 & 4545.252 & 6501.153 \\
\hline Age $>70$ & $-6447.423 * *$ & $-8341.407 * * *$ & $-11264.840^{* * *}$ & $-14735.900 * * *$ & $-14550.850 * * *$ & $-12994.230 * * *$ & $-12366.410^{*}$ \\
\hline Tertiary education of taxpayer & $8508.249 * * *$ & $8497.437 * * *$ & $8357.043 * * *$ & $11959.080 * * *$ & $18198.620 * * *$ & $20175.090 * * *$ & $23201.930 * * *$ \\
\hline Tertiary education of taxpayer's partner & 2877.953 & $3945.217(*)$ & $5668.173 *$ & $7792.310^{*}$ & 8499.771 & 10834.510 & 18376.960 \\
\hline Retired & $-5339.923 * * *$ & $-8234.741 * * *$ & $-7676.441 * * *$ & $-7309.485^{* * *}$ & $-7041.537 *$ & $-7938.025 *$ & $-6584.457 *$ \\
\hline Unemployed & -2375.552 & $-3636.779 *$ & $-4445.913^{* *}$ & $-5386.472 *$ & -4483.800 & -2342.072 & -4411.653 \\
\hline Self-employed & $-6250.392 * * *$ & $-5246.756 * * *$ & $-3969.901 * *$ & -1431.212 & 3203.871 & 6743.710 & $25685.560 * *$ \\
\hline Household located in city & -1928.160 & 252.086 & 1215.301 & $3690.211^{*}$ & 2563.019 & 3221.041 & 5321.295 \\
\hline
\end{tabular}


Table A6 (cont.): Quantile Regressions for Pre-Tax Household Income, 4178 Observations

\begin{tabular}{|c|c|c|c|c|c|c|c|}
\hline & $10^{\text {th }}$ quantile & $20^{\text {th }}$ quantile & $30^{\text {th }}$ quantile & $50^{\text {th }}$ quantile & $70^{\text {th }}$ quantile & $80^{\text {th }}$ quantile & $90^{\text {th }}$ quantile \\
\hline House owner & $8492.471^{* * *}$ & $8957.818 * * *$ & $9089.228 * * *$ & $10810.340 * * *$ & $13795.600 * * *$ & $16042.200 * * *$ & $21338.870^{* * *}$ \\
\hline Other capital income $>0$ & $6701.337 * * *$ & $6626.990 * * *$ & $7352.770 * * *$ & $8047.676 * * *$ & $6903.086 * * *$ & $8142.721 * * *$ & $9274.578 * * *$ \\
\hline Farmer & $-8124.026^{* * *}$ & $-8869.156 * * *$ & $-8442.356^{* * *}$ & $-8128.584 * * *$ & $-10374.780 * *$ & $-12443.410^{* * *}$ & $-13087.910 * * *$ \\
\hline Income compensation due to military service & $-12306.070 *$ & -7323.572 & -6254.360 & -6454.451 & -3396.917 & -6157.690 & 22257.480 \\
\hline Income compensation due to illness/accident & -3927.982 & -3237.678 & 1630.351 & 781.449 & -600.643 & -4562.339 & -4414.985 \\
\hline Community size 2 & 40.047 & -197.327 & 581.693 & 848.063 & 2120.637 & 2405.458 & 2684.072 \\
\hline Community size 3 & 2026.458 & 1537.799 & 1224.735 & 1615.728 & 2053.971 & 2285.769 & 8058.369* \\
\hline Community size 4 & 2430.418 & 1716.902 & 1252.620 & 1470.923 & 3432.542 & 5150.357 & 9016.200 \\
\hline Community size 5 & 1121.033 & 748.851 & 262.979 & 76.146 & 2460.000 & 5174.924 & 10528.760 \\
\hline Community size 6 & 2718.523 & 1499.982 & 1313.984 & 2298.019 & 5357.338 & 8444.680(*) & $12829.000(*)$ \\
\hline Community type 2 & 643.707 & 494.563 & 18.163 & -744.196 & -646.567 & 437.542 & -1057.860 \\
\hline Community type 3 & 564.761 & 282.104 & 30.005 & 878.806 & 3602.598 & 7211.652(*) & $16380.330 * *$ \\
\hline Community type 4 & -2806.865 & -229.015 & -844.166 & -850.065 & -724.598 & 2130.305 & 4839.206 \\
\hline Community type 5 & -2994.786 & -1920.128 & -2033.716 & -55.442 & -1346.933 & 417.954 & 5486.537 \\
\hline Community type 6 & -1881.639 & -1254.259 & -1446.081 & -400.104 & -18.785 & 3810.642 & 8858.380 \\
\hline Community type 7 & -4657.601 & $-4020.962(*)$ & -3689.535 & -2017.983 & -293.075 & 2930.401 & 6084.611 \\
\hline Community type 8 & -3149.965 & -1286.696 & -1550.311 & 3512.091 & 1602.839 & 5633.906 & 6583.915 \\
\hline Constant & 17235.390 & 43045.110 & 77639.930 & 41925.670 & 2669.622 & 14280.830 & 92102.360 \\
\hline
\end{tabular}


Table A7: Quantile Regressions for Post-Tax (and -Transfer) Household Income, 4178 Observations

\begin{tabular}{|c|c|c|c|c|c|c|c|}
\hline & $10^{\text {th }}$ quantile & $20^{\text {th }}$ quantile & $30^{\text {th }}$ quantile & $50^{\text {th }}$ quantile & $70^{\text {th }}$ quantile & $80^{\text {th }}$ quantile & $90^{\text {th }}$ quantile \\
\hline Direct Democracy & -881.204 & -898.465 & -1449.298 & -1645.376 & -941.291 & -1599.494 & -1311.208 \\
\hline Number of partiesin the cantonal government & 664.749 & 263.931 & -594.390 & -571.511 & 720.867 & -702.587 & -2070.014 \\
\hline Log of population & -411.092 & -386.567 & 94.048 & 83.811 & 364.905 & -269.034 & -893.300 \\
\hline Fiscal constraints & -321.997 & -176.454 & -923.235 & $-1472.606(*)$ & -661.658 & -1052.688 & -1041.618 \\
\hline Fiscal decentralization & 4253.013 & 1334.780 & -350.111 & -2446.342 & -2748.094 & 5090.691 & 14739.720 \\
\hline Tax competition & 4325.227 & 548.557 & 3036.547 & 7195.319* & 4882.387 & 6404.603 & 9233.536 \\
\hline Log of unconditional grants & -5145.777 & -5612.264 & -8693.671 & -8257.583 & -2492.767 & -8628.822 & -13028.470 \\
\hline Net share of conservative parties in the government & -3846.151 & $-6829.130(*)$ & -6990.375 & -2720.467 & 338.758 & -976.778 & 4230.712 \\
\hline Urbanization & -23.182 & -67.590 & -156.030 & -102.035 & 38.550 & -106.972 & -208.817 \\
\hline Share of young population & 114.439 & -152.427 & -309.164 & -50.072 & 1435.334 & 1198.663 & 182.258 \\
\hline Share of old population & 98.601 & 27.933 & 9.605 & -116.633 & 721.740 & 1001.811 & 506.416 \\
\hline Log of national income & 2322.356 & 7071.916 & 15895.680 & 17999.720 & 17452.420 & 38836.410 & $49366.690(*)$ \\
\hline Dummy for French or Italian language & -1424.649 & -3250.331 & -2107.140 & 636.354 & -1051.407 & 1129.252 & 6875.328 \\
\hline Female & 1446.846 & 1169.905 & 168.379 & -1947.721 & $-5013.003 * *$ & -7211.138 & $-8164.472 *$ \\
\hline Swiss /permanent resident & 960.843 & 1063.281 & 1717.569 & -1195.956 & -1934.905 & -1029.497 & -384.279 \\
\hline Cohabiting & $10019.860 * * *$ & $9075.589 * * *$ & $8325.406^{* * *}$ & $7128.337 * * *$ & $4522.718^{*}$ & 4500.746 & 2863.549 \\
\hline Married & $-2536.402(*)$ & $-2864.995^{*}$ & $-3687.028(*)$ & $-5848.429 * *$ & $-7375.116^{*}$ & $-8418.296 *$ & $-10194.640 *$ \\
\hline Married with kids & 3212.575 & 148.993 & -3620.945 & $-7930.846^{* * *}$ & $-12930.220 * * *$ & -14266.860 & $-17670.920 * * *$ \\
\hline Single & $2615.004 *$ & 2199.195* & 1178.017 & 173.876 & -1294.996 & -1845.017 & -3245.296 \\
\hline Single parent & $-11640.510 * * *$ & $-14411.510 * * *$ & $-12407.120 * * *$ & $-13562.400 * * *$ & $-13138.110 * * *$ & $-14296.800 * *$ & $-16264.950 * *$ \\
\hline Age $30-39$ & 1073.979 & 321.998 & 314.955 & $1879.057^{*}$ & 2957.881(*) & $3697.228 *$ & $4474.179 *$ \\
\hline Age $40-49$ & 1652.182 & 1149.865 & 1455.360 & $2863.276^{* *}$ & $4591.578^{*}$ & $6871.029(*)$ & $9091.207 * * *$ \\
\hline Age 50 - 59 & 51.797 & -412.534 & -1436.103 & 498.968 & $4283.673 *$ & 6359.398 & $6263.519(*)$ \\
\hline Age 60 - 69 & $-3011.571\left(^{*}\right)$ & $-4158.220 * *$ & $-4624.751(*)$ & $-3517.474(*)$ & 34.959 & 2649.808 & 3674.108 \\
\hline Age $>70$ & $-5682.358 * * *$ & $-7165.832 * * *$ & $-10002.530 * * *$ & $-13108.690 * * *$ & $-11999.350 * * *$ & $-11026.680^{* * *}$ & $-11336.000^{* *}$ \\
\hline Tertiary education of taxpayer & $6981.850 * * *$ & $7113.875 * * *$ & $7229.981 * * *$ & $10056.770 * * *$ & $14301.720 * * *$ & $16133.540 *$ & $21121.800^{* *}$ \\
\hline Tertiary education of taxpayer's partner & 4295.119(*) & 4677.098* & $5502.040(*)$ & $4989.511(*)$ & $7817.163(*)$ & 9622.305 & 18869.360 \\
\hline Retired & $-4563.729 * * *$ & $-6772.031 * * *$ & $-6714.845^{* * *}$ & $-5821.558 * *$ & $-6203.118 * * *$ & -6759.444 & $-5253.834^{*}$ \\
\hline Unemployed & -2177.943 & $-2912.450 *$ & $-4069.401 * *$ & $-4541.043^{*}$ & -2697.333 & -3236.180 & $-4452.018(*)$ \\
\hline Self-employed & $-5690.124 * * *$ & $-4929.698 * * *$ & $-4187.232 * * *$ & -780.108 & 2876.621 & $5437.423(*)$ & $24062.120^{* *}$ \\
\hline Household located in city & -1761.971 & 156.578 & 1385.184 & $2836.802(*)$ & 2107.457 & 2277.513 & 5053.918 \\
\hline
\end{tabular}


Table A7 (cont.): Quantile Regressions for Post-Tax (and -Transfer) Household Income, 4178 Observations

\begin{tabular}{|c|c|c|c|c|c|c|c|}
\hline & $10^{\text {th }}$ quantile & $20^{\text {th }}$ quantile & $30^{\text {th }}$ quantile & $50^{\text {th }}$ quantile & $70^{\text {th }}$ quantile & $80^{\text {th }}$ quantile & $90^{\text {th }}$ quantile \\
\hline House owner & $8202.289 * * *$ & $8503.905^{* * *}$ & $8258.967 * * *$ & $9797.253^{* * *}$ & $13382.760 * * *$ & $14441.980 * * *$ & $19831.680^{* * *}$ \\
\hline Other capital income $>0$ & $5797.935 * * *$ & $6173.075 * * *$ & $6695.878 * * *$ & $7324.541^{* * *}$ & $6107.580 * * *$ & $7390.629 *$ & $7544.697 * * *$ \\
\hline Farmer & $-8212.738 * * *$ & $-8390.692 * * *$ & $-7924.936 * *$ & $-7656.908 * * *$ & $-9761.708 * * *$ & $-11174.580 * * *$ & $-11436.110 *$ \\
\hline Income compensation due to military service & $-10190.110^{*}$ & -6180.449 & -4350.213 & -5780.453 & -4585.161 & -5955.720 & 20991.990 \\
\hline Income compensation due to illness/accident & -2389.402 & -1945.545 & 2691.838 & 505.552 & -3572.992 & -2581.754 & -4085.489 \\
\hline Community size 2 & 335.766 & -112.484 & 795.573 & 400.088 & 1252.550 & 1585.107 & 3324.861 \\
\hline Community size 3 & $1870.424(*)$ & 901.238 & 951.792 & 1162.071 & 1610.278 & 1393.647 & $7445.266(*)$ \\
\hline Community size 4 & 1278.545 & 733.112 & 1136.339 & 804.108 & $3255.247(*)$ & 4459.640 & 8424.576 \\
\hline Community size 5 & 1090.904 & 369.677 & 387.816 & 326.463 & 2410.492 & 4120.181 & 9595.616 \\
\hline Community size 6 & 1701.455 & 650.237 & 1409.913 & 1541.147 & $4432.940(*)$ & 6148.905 & 11118.810 \\
\hline Community type 2 & 747.063 & 827.669 & 113.599 & -874.253 & -650.128 & 84.760 & -1626.183 \\
\hline Community type 3 & -85.766 & -253.695 & 7.104 & 394.151 & 3171.164 & 6243.819 & $14175.430 *$ \\
\hline Community type 4 & -2458.278 & -142.108 & -67.870 & -1310.193 & -1739.930 & 798.800 & 4676.686 \\
\hline Community type 5 & $-3338.664 *$ & $-2125.528(*)$ & -1197.872 & -156.490 & -1403.074 & -197.382 & 4650.079 \\
\hline Community type 6 & -2706.313 & -1315.679 & -950.072 & -628.324 & 344.957 & 3683.686 & 9129.067 \\
\hline Community type 7 & -3584.903 & -3484.264 & -2309.110 & -2513.785 & -1081.191 & 2026.849 & 5239.491 \\
\hline Community type 8 & -2789.330 & -2529.244 & -1101.250 & 945.246 & 252.772 & 2003.926 & 5592.574 \\
\hline Constant & 44497.370 & 43629.410 & 47895.760 & 48560.520 & -50255.330 & -65070.270 & -21864.180 \\
\hline
\end{tabular}


Table A8: Quantile Regressions for Difference between Pre - and Post-Tax Household Income, 4178 Observations

\begin{tabular}{|c|c|c|c|c|c|c|c|}
\hline & $10^{\text {th }}$ quantile & $20^{\text {th }}$ quantile & $30^{\text {th }}$ quantile & $50^{\text {th }}$ quantile & $70^{\text {th }}$ quantile & $80^{\text {th }}$ quantile & $90^{\text {th }}$ quantile \\
\hline Direct Democracy & $-293.799 *$ & $-309.411^{* *}$ & $-358.607^{* *}$ & $-405.208 *$ & $-645.401^{* *}$ & $-904.024 * * *$ & $-1129.295 *$ \\
\hline Number of parties in the cantonal government & -126.747 & $-271.054(*)$ & -132.184 & -263.888 & -374.262 & -108.233 & -332.340 \\
\hline Log of population & -92.597 & -82.556 & -136.420 & 92.788 & 65.204 & -81.149 & -30.725 \\
\hline Fiscal constraints & $-148.003 *$ & $-210.436 * *$ & $-165.965 *$ & $-195.329(*)$ & -246.819 & -192.859 & -52.734 \\
\hline Fiscal decentralization & 754.492 & 471.373 & -17.746 & -1343.735 & -1633.987 & $-4305.268 *$ & -5014.086 \\
\hline Tax competition & 90.354 & $738.489 *$ & $847.908 *$ & 609.572 & 827.344 & 13.658 & -689.664 \\
\hline Log of unconditional grants & $-1296.365^{*}$ & $-1664.863 * *$ & $-1281.174 *$ & -1407.456 & -1813.288 & -1460.019 & -1094.394 \\
\hline Net share of conservative parties in the government & $-2011.854^{* * *}$ & $-1160.023 *$ & -733.741 & $-1767.575^{* *}$ & $-2138.030 *$ & $-3429.064 * *$ & $-3643.303 *$ \\
\hline Urbanization & $-36.206^{* * *}$ & $-38.574 * * *$ & $-36.643 * * *$ & $-43.175 * *$ & $-61.724 * *$ & $-66.295 *$ & -68.948 \\
\hline Share of young population & $-179.459(*)$ & $-206.204 *$ & $-234.634 *$ & -179.077 & $-388.201(*)$ & $-561.832 *$ & $-777.680(*)$ \\
\hline Share of old population & -48.957 & -41.882 & -22.018 & 34.480 & -66.828 & -158.137 & -375.737 \\
\hline Log of national income & 782.029 & 1103.334 & 507.113 & 936.161 & 713.124 & -603.578 & -1166.310 \\
\hline Dummy for French or Italian language & $-712.766^{*}$ & -111.533 & -266.294 & -532.503 & -547.512 & $-1881.149(*)$ & $-2781.49\left(^{*}\right)$ \\
\hline Female & 155.946 & 13.000 & -31.700 & $-394.811 * *$ & $-743.493 * *$ & $-987.922 * *$ & $-1461.022 * *$ \\
\hline Swiss /permanent resident & $310.335^{*}$ & $303.927(*)$ & $281.405(*)$ & 158.306 & -139.510 & -265.059 & -316.368 \\
\hline Cohabiting & $1238.147 * * *$ & $1274.536 * * *$ & $1101.227 * * *$ & $1187.834^{* * *}$ & $985.205^{* * *}$ & $1221.578 * *$ & 575.163 \\
\hline Married & $-753.339 * * *$ & $-744.896 * * *$ & $-547.258 * *$ & $-933.380 * * *$ & $-1024.006 * * *$ & $-1406.173^{* *}$ & $-1470.918 *$ \\
\hline Married with kids & $741.346^{* * *}$ & 196.176 & $-425.595 *$ & $-909.859 * * *$ & $-1671.757 * * *$ & $-1878.867 * * *$ & $-2907.345^{* * *}$ \\
\hline Single & 75.250 & 100.424 & 73.620 & 136.577 & 215.958 & 393.486 & 20.655 \\
\hline Single parent & $-736.066 * * *$ & $-1199.192^{* * *}$ & $-1483.655^{* * *}$ & $-1762.376^{* * *}$ & $-1906.548 * * *$ & $-2464.928 * * *$ & $-3554.534 * * *$ \\
\hline Age $30-39$ & -97.842 & -74.413 & 2.299 & 132.756 & $515.746^{* *}$ & $753.804 * * *$ & $900.869 * *$ \\
\hline Age $40-49$ & -79.093 & 149.426 & $216.983(*)$ & $424.314 * *$ & $947.088^{* * *}$ & $1375.375^{* * *}$ & $1992.554 * * *$ \\
\hline Age $50-59$ & 29.073 & 129.725 & 138.428 & $335.296(*)$ & $613.363 * *$ & $1012.718^{* *}$ & $1478.924 * *$ \\
\hline Age $60-69$ & $-332.368 *$ & $-555.275 * * *$ & $-603.369 * *$ & $-397.338(*)$ & 22.762 & 451.803 & $1511.283 *$ \\
\hline Age $>70$ & $-407.842 * *$ & $-810.309 * * *$ & $-1146.139 * * *$ & $-1705.237 * * *$ & $-1718.505^{* * *}$ & $-1502.559 * * *$ & $-1475.102 *$ \\
\hline Tertiary education of taxpayer & $674.526 * * *$ & $817.512 * * *$ & $1245.320 * * *$ & $1753.343 * * *$ & $2519.994 * * *$ & $3165.584 * * *$ & $4879.550 * * *$ \\
\hline Tertiary education of taxpayer's partner & 20.336 & 358.229 & 447.400 & $1278.902 *$ & $1236.728 *$ & 1371.723 & $4520.584(*)$ \\
\hline Retired & $-737.766 * * *$ & $-971.403 * * *$ & $-1065.241^{* * *}$ & $-1139.152 * * *$ & $-1334.776^{* * *}$ & $-1451.249 * * *$ & $-1326.744 *$ \\
\hline Unemployed & $-371.947 *$ & $-362.225 *$ & $-401.404^{* *}$ & $-814.682 * * *$ & $-849.258 *$ & -426.154 & -316.444 \\
\hline Self-employed & $-610.526 * * *$ & $-638.040 * * *$ & $-470.180 * *$ & $-307.811(*)$ & 180.150 & 568.686 & $2171.059\left(^{*}\right)$ \\
\hline Household located in city & -5.149 & 2.839 & 68.704 & 122.977 & 381.342 & $707.596 *$ & 625.288 \\
\hline House owner & $333.534^{* * *}$ & $366.000 * * *$ & $353.834 * * *$ & $561.110 * * *$ & $930.071 * * *$ & $1403.258 * * *$ & $2145.574 * * *$ \\
\hline
\end{tabular}


Table A8 (cont.): Quantile Regressions for Difference between Pre - and Post-Tax Household Income, 4178 Observations

\begin{tabular}{|c|c|c|c|c|c|c|c|}
\hline & $10^{\text {th }}$ quantile & $20^{\text {th }}$ quantile & $30^{\text {th }}$ quantile & $50^{\text {th }}$ quantile & $70^{\text {th }}$ quantile & $80^{\text {th }}$ quantile & $90^{\text {th }}$ quantile \\
\hline Other capital income $>0$ & $404.204 * * *$ & $576.034 * * *$ & $689.086 * * *$ & $725.671 * * *$ & $938.883^{* * *}$ & $1040.530 * * *$ & $1231.303^{* * *}$ \\
\hline Farmer & $-547.129 * * *$ & $-517.862 * * *$ & $-549.708 * * *$ & $-589.709 * * *$ & $-829.549 * * *$ & $-1111.733^{* * *}$ & $-1696.872 * * *$ \\
\hline $\begin{array}{l}\text { Income compensation } \\
\text { due to military service }\end{array}$ & -553.350 & -501.132 & $-680.123(*)$ & -856.288 & -23.131 & 264.179 & 976.179 \\
\hline $\begin{array}{l}\text { Income compensation } \\
\text { due to illness/accident }\end{array}$ & 131.138 & -255.185 & -311.293 & -252.629 & 1.184 & -709.571 & 1032.700 \\
\hline Community size 2 & 78.221 & 83.565 & 83.924 & 119.704 & 128.576 & 145.400 & 124.168 \\
\hline Community size 3 & 81.473 & 167.002 & 97.551 & 99.574 & 200.080 & 463.240 & 354.490 \\
\hline Community size 4 & 43.624 & 109.311 & 102.467 & 123.531 & 200.796 & 91.572 & 328.393 \\
\hline Community size 5 & -294.655 & -207.424 & -245.150 & -268.688 & -161.657 & -150.616 & 346.375 \\
\hline Community size 6 & -117.067 & 255.610 & 200.276 & 306.031 & $947.530 *$ & 794.831 & $1810.918(*)$ \\
\hline Community type 2 & -166.029 & -61.531 & -68.704 & -54.249 & -129.293 & -310.818 & -87.938 \\
\hline Community type 3 & -202.695 & -167.540 & -158.654 & -46.894 & 9.481 & 191.395 & 833.291 \\
\hline Community type 4 & -278.916 & -223.018 & -230.517 & -353.143 & -346.497 & -294.291 & -514.776 \\
\hline Community type 5 & -290.121 & -205.661 & -147.836 & $-386.664(*)$ & -324.765 & -179.952 & -128.808 \\
\hline Community type 6 & $-395.277(*)$ & $-298.841(*)$ & -231.636 & $-473.035\left(^{*}\right)$ & -272.680 & -260.749 & 699.846 \\
\hline Community type 7 & -358.039 & -317.434 & $-363.454(*)$ & $-610.777(*)$ & -334.171 & -47.123 & -77.011 \\
\hline Community type 8 & -465.949 & -220.000 & -345.086 & -623.172 & 288.205 & 213.588 & 223.101 \\
\hline Constant & $15626.900 *$ & $19406.010^{* *}$ & $20862.910 * *$ & 17249.910 & 32102.760* & 43855.950* & 55447.980 \\
\hline
\end{tabular}


Table A9: Quantile Regressions for Income Difference with predicted Pre-Tax Income, 4174 Observations

\begin{tabular}{|c|c|c|c|c|c|c|c|}
\hline & $10^{\text {th }}$ quantile & $20^{\text {th }}$ quantile & $30^{\text {th }}$ quantile & $50^{\text {th }}$ quantile & $70^{\text {th }}$ quantile & 80th quantile & $90^{\text {th }}$ quantile \\
\hline Direct Democracy & $-324.958 * *$ & $-272.174 *$ & $-284.219 *$ & -108.648 & -308.565 & $-564.656^{*}$ & -727.442 \\
\hline predicted Pre-tax income & -0.001 & $0.016^{* *}$ & $0.031 * * *$ & $0.063 * * *$ & $0.113^{* * *}$ & $0.149 * * *$ & $0.189 * * *$ \\
\hline Number of parties in the cantonal government & -153.786 & $-259.832(*)$ & -112.891 & -108.497 & -352.509 & -329.932 & -521.937 \\
\hline Log of population & -108.725 & -88.341 & -105.086 & 55.582 & -26.198 & -156.197 & -273.477 \\
\hline Fiscal constraints & $-162.891 *$ & $-184.425^{*}$ & -133.162 & -33.379 & -81.229 & 8.555 & -29.721 \\
\hline Fiscal decentralization & 890.450 & 381.810 & -366.776 & -1521.887 & -1921.155 & $-4657.086 *$ & -4149.671 \\
\hline Tax competition & 178.996 & 550.228 & $600.675(*)$ & -29.794 & -133.690 & -901.824 & -1150.712 \\
\hline Log of unconditional grants & $-1422.170 *$ & $-1499.579 *$ & $-1088.363(*)$ & -630.057 & -1520.029 & -1577.330 & -2433.965 \\
\hline Net share of conservative parties in the government & $-1980.560 * * *$ & $-1089.556 *$ & $-778.579(*)$ & $-1302.074 *$ & $-2028.200 *$ & $-2995.002 * *$ & $-2799.639(*)$ \\
\hline Urbanization & $-38.409 * * *$ & $-34.839 * * *$ & $-28.813^{*}$ & -25.932 & -40.864 & $-49.525 *$ & $-63.322(*)$ \\
\hline Share of young population & $-191.893(*)$ & $-187.816^{*}$ & $-188.617(*)$ & -152.849 & -307.150 & $-513.317^{*}$ & $-750.389(*)$ \\
\hline Share of old population & -52.410 & -44.551 & -11.723 & 25.243 & -61.314 & -221.429 & -388.754 \\
\hline Log of national income & 970.492 & 838.869 & -260.537 & -1296.716 & -1540.416 & -2688.984 & -2645.250 \\
\hline Dummy for French or Italian language & $-679.283 *$ & -93.648 & -179.824 & -192.319 & -17.895 & -1003.359 & -513.518 \\
\hline Female & 141.401 & 108.172 & 139.676 & 33.598 & -63.760 & 24.771 & -748.837 \\
\hline Swiss /permanent resident & $317.025^{*}$ & $338.959 *$ & $268.830(*)$ & 185.294 & -176.058 & $-699.564(*)$ & -642.349 \\
\hline Cohabiting & $1234.586^{* * *}$ & $1205.562 * * *$ & $997.115^{* * *}$ & $812.282^{* * *}$ & $673.505^{* *}$ & 358.253 & 2.340 \\
\hline Married & $-745.718 * * *$ & $-659.737 * * *$ & $-393.455^{*}$ & $-387.679(*)$ & -466.089 & -301.575 & -749.005 \\
\hline Married with kids & $706.636^{* * *}$ & $481.423 *$ & 34.620 & -68.083 & 173.841 & 205.697 & 153.812 \\
\hline Single & 72.976 & 147.525 & 125.977 & $233.619\left(^{*}\right)$ & 220.356 & 371.032 & 222.911 \\
\hline Single parent & $-777.636 * * *$ & $-820.356^{* * *}$ & $-829.944 * *$ & -500.941 & -60.928 & -164.636 & 506.611 \\
\hline Age 30 - 39 & -96.789 & $-176.961\left(^{*}\right)$ & -50.751 & -73.714 & 36.447 & 95.502 & 169.339 \\
\hline Age 40 - 49 & -55.767 & -2.217 & -29.081 & -151.589 & -12.521 & 11.715 & 435.458 \\
\hline Age 50 - 59 & 11.720 & 103.349 & -33.554 & 80.274 & 165.004 & 203.633 & 504.292 \\
\hline Age 60 - 69 & $-342.772 *$ & $-564.742 * * *$ & $-725.247 * * *$ & $-637.827 * *$ & -347.938 & -498.310 & 740.327 \\
\hline Age $>70$ & $-431.921 * *$ & $-653.215^{* * *}$ & $-941.447 * * *$ & $-1257.156^{* * *}$ & $-801.850 *$ & -653.507 & 234.615 \\
\hline Tertiary education of taxpayer & $676.731 * *$ & $537.680 * *$ & $662.963 * *$ & $596.679 *$ & 273.339 & 331.793 & 403.844 \\
\hline Tertiary education of taxpayer's partner & 44.694 & 143.170 & -69.090 & 136.897 & 74.620 & -544.585 & 2345.687 \\
\hline Retired & $-734.572 * * *$ & $-836.044 * * *$ & $-753.238 * * *$ & $-517.622 *$ & -255.244 & 126.116 & 382.874 \\
\hline Unemployed & $-307.460(*)$ & $-309.197 *$ & $-334.226(*)$ & -222.029 & -163.208 & -94.014 & 869.342 \\
\hline Self-employed & $-594.121 * * *$ & $-776.103 * * *$ & $-722.535 * * *$ & $-659.600 * * *$ & -442.339 & -418.757 & 791.934 \\
\hline Household located in city & 6.364 & -69.591 & -46.524 & -118.150 & -119.098 & -3.097 & -613.055 \\
\hline
\end{tabular}


Table A9 (cont.): Quantile Regressions for Income Difference with predicted Pre-Tax Income, 4174 Observations

\begin{tabular}{|c|c|c|c|c|c|c|c|}
\hline & $10^{\text {th }}$ quantile & $20^{\text {th }}$ quantile & $30^{\text {th }}$ quantile & $50^{\text {th }}$ quantile & $70^{\text {th }}$ quantile & 80th quantile & $90^{\text {th }}$ quantile \\
\hline House owner & $357.158 * * *$ & 109.666 & -92.178 & $-465.746 * *$ & $-998.771 * * *$ & $-1069.848 * *$ & $-1227.919 *$ \\
\hline Other capital income $>0$ & $398.676 * * *$ & $401.591^{* * *}$ & $377.762 * * *$ & 124.730 & -122.634 & $-348.945(*)$ & $-810.923 *$ \\
\hline Farmer & $-564.893 * * *$ & $-374.860 * *$ & -166.504 & 75.603 & 410.240 & 818.219* & 660.937 \\
\hline Income compensation due to military service & -568.329 & $-447.091(*)$ & $-784.179 * *$ & -871.107 & 248.837 & 353.869 & -294.247 \\
\hline Income compensation due to illness/accident & 133.751 & -253.476 & -337.995 & -68.911 & -6.963 & 223.061 & 1008.639 \\
\hline Community size 2 & 88.252 & 55.043 & 45.209 & 72.551 & 4.149 & -36.345 & -95.505 \\
\hline Community size 3 & 108.143 & 74.001 & -33.975 & -122.340 & -168.119 & -202.595 & -159.864 \\
\hline Community size 4 & 78.336 & -15.550 & -141.239 & -288.736 & $-667.450\left(^{*}\right)$ & $-862.493 *$ & -758.818 \\
\hline Community size 5 & -238.391 & -289.371 & $-435.532 *$ & $-511.999(*)$ & -793.189 & -798.887 & -122.073 \\
\hline Community size 6 & -40.542 & 124.744 & 40.349 & 229.446 & 492.840 & 652.650 & 1111.636 \\
\hline Community type 2 & -158.973 & -11.338 & 33.217 & 164.847 & 111.739 & 228.603 & 619.390 \\
\hline Community type 3 & -168.706 & -198.556 & $-312.324 *$ & -221.920 & -444.297 & -326.470 & -48.231 \\
\hline Community type 4 & -236.828 & -187.196 & -246.215 & -302.713 & -484.520 & -169.166 & -719.560 \\
\hline Community type 5 & -248.024 & -184.275 & -162.113 & -302.476 & -418.989 & -82.920 & -175.791 \\
\hline Community type 6 & $-362.660\left(^{*}\right)$ & $-286.880\left(^{*}\right)$ & $-359.616^{*}$ & $-545.577 *$ & -701.154 & -484.161 & -59.235 \\
\hline Community type 7 & -316.563 & -252.493 & -242.758 & -301.478 & -249.886 & 533.748 & 905.474 \\
\hline Community type 8 & -450.335 & -241.568 & -382.344 & -441.783 & -328.559 & 188.225 & -261.985 \\
\hline Constant & 16716.110* & 17779.370 ** & 18596.350* & 14573.420 & 29595.150(*) & $45228.150 * *$ & $62863.400\left(^{*}\right)$ \\
\hline
\end{tabular}


Table A10: Quantile Regressions for Income Difference with original Pre-Tax Income, 4178 Observations

\begin{tabular}{|c|c|c|c|c|c|c|c|}
\hline & $10^{\text {th }}$ quantile & $20^{\text {th }}$ quantile & $30^{\text {th }}$ quantile & $50^{\text {th }}$ quantile & $70^{\text {th }}$ quantile & $80^{\text {th }}$ quantile & $90^{\text {th }}$ quantile \\
\hline Direct Democracy & $-309.271^{* *}$ & $-382.801 * * *$ & $-393.587 * * *$ & -251.039 & -182.899 & -129.624 & -23.910 \\
\hline Pre-tax income & $0.060 * * *$ & $0.081^{* * *}$ & $0.098 * * *$ & $0.120 * * *$ & $0.142 * * *$ & $0.159 * * *$ & $0.170 * * *$ \\
\hline Number of parties in the cantonal government & -84.963 & $-354.969 * *$ & $-368.030 * *$ & -72.145 & 42.412 & 139.694 & 265.840 \\
\hline Log of population & -83.437 & -74.325 & -103.119 & -43.896 & -15.856 & -34.910 & 13.537 \\
\hline Fiscal constraints & $-115.323(*)$ & $-202.423 * * *$ & $-210.539 * * *$ & -50.674 & 40.874 & 105.271 & $186.409(*)$ \\
\hline Fiscal decentralization & 772.913 & $1008.957 *$ & $872.829 *$ & -1032.386 & $-2061.159 *$ & $-2872.890 * * *$ & $-3350.535 * *$ \\
\hline Tax competition & 109.451 & $643.032(*)$ & $731.603^{* *}$ & -75.305 & -640.070 & $-1005.688 *$ & $-1840.600 * * *$ \\
\hline Log of unconditional grants & $-1444.563 * *$ & $-2168.938 * * *$ & $-2090.090 * * *$ & -303.564 & 1030.749 & $1792.514^{*}$ & $3049.926 * *$ \\
\hline Net share of conservative parties in the government & $-2070.003 * * *$ & $-1652.590 * * *$ & $-1255.271^{* * *}$ & -949.067 & -841.865 & -264.889 & 118.381 \\
\hline Urbanization & $-43.398 * * *$ & $-55.208 * * *$ & $-54.215 * * *$ & -28.612 & -14.745 & 1.800 & 25.566 \\
\hline Share of young population & $-264.250 * *$ & $-315.473 * * *$ & $-340.988 * * *$ & -297.264 & $-369.345^{*}$ & $-338.931 *$ & -222.193 \\
\hline Share of old population & -92.255 & -67.234 & -75.221 & -81.397 & -169.416 & $-179.615 *$ & -148.465 \\
\hline Log of national income & -34.245 & 1022.392 & 597.596 & $-2111.737(*)$ & $-4268.094^{* *}$ & $-5504.793 * * *$ & $-6737.652 * * *$ \\
\hline Dummy for French or Italian language & $-685.856(*)$ & -2.901 & 124.193 & -393.694 & $-816.414^{*}$ & $-1055.243 *$ & $-1362.279 *$ \\
\hline Female & 53.224 & 52.546 & 15.719 & -91.504 & -116.558 & -148.972 & -106.101 \\
\hline Swiss /permanent resident & $347.903(*)$ & 140.347 & 36.555 & -117.519 & $-277.026 *$ & $-276.478(*)$ & $-490.315(*)$ \\
\hline Cohabiting & $584.408 * * *$ & $449.297 * * *$ & $387.397 * * *$ & 274.450 & -225.844 & $-423.109(*)$ & $-636.546 *$ \\
\hline Married & $-348.509 * *$ & $-270.294^{*}$ & $-220.071\left(^{*}\right)$ & -275.970 & 113.185 & -4.834 & 57.188 \\
\hline Married with kids & $430.671^{* *}$ & $306.932 *$ & $272.659(*)$ & 188.990 & $-445.106 *$ & $-540.550(*)$ & $-926.302 * *$ \\
\hline Single & 110.067 & 79.536 & $134.239(*)$ & 146.059 & 42.322 & -107.925 & -160.128 \\
\hline Single parent & 26.712 & -54.427 & -22.940 & 66.706 & 68.033 & 237.048 & 578.322 \\
\hline Age $30-39$ & -107.187 & $-111.497(*)$ & -70.758 & -4.097 & 65.725 & 57.505 & 64.084 \\
\hline Age $40-49$ & -106.144 & -35.350 & 28.962 & 149.046 & 192.177 & $176.317(*)$ & 165.057 \\
\hline Age $50-59$ & 34.771 & 107.024 & $164.243(*)$ & $172.696(*)$ & 174.985 & $275.615(*)$ & 197.731 \\
\hline Age 60 - 69 & $-242.230 *$ & -135.706 & -40.068 & 34.552 & 203.818 & $417.269 *$ & $419.182(*)$ \\
\hline Age $>70$ & $-238.445^{*}$ & -194.865 & -71.850 & 64.719 & 331.090* & $515.240 * * *$ & 360.213 \\
\hline Tertiary education of taxpayer & 173.746 & $252.907 *$ & $184.661(*)$ & 332.306 & $313.163 *$ & $356.528(*)$ & 377.646 \\
\hline Tertiary education of taxpayer's partner & 33.083 & -24.099 & 63.998 & 59.089 & 41.096 & 215.885 & 173.934 \\
\hline Retired & $-311.063 * *$ & $-355.666 * * *$ & $-380.370 * * *$ & $-394.484 * * *$ & $-480.588 * * *$ & $-452.372 * * *$ & -279.233 \\
\hline Unemployed & $-277.263(*)$ & -92.612 & -12.876 & -124.778 & 98.607 & 79.886 & -176.229 \\
\hline Self-employed & $-564.849 * * *$ & $-360.403 * *$ & $-281.037 * *$ & -39.829 & 165.844 & $346.009 *$ & $772.487 * * *$ \\
\hline Household located in city & -24.166 & 23.971 & 64.823 & 193.895 & 155.084 & 94.007 & -38.648 \\
\hline
\end{tabular}


Table A10 (cont.): Quantile Regressions for Income Difference with original Pre-Tax Income, 4178 Observations

\begin{tabular}{|c|c|c|c|c|c|c|c|}
\hline & $10^{\text {th }}$ quantile & $20^{\text {th }}$ quantile & $30^{\text {th }}$ quantile & $50^{\text {th }}$ quantile & $70^{\text {th }}$ quantile & $80^{\text {th }}$ quantile & $90^{\text {th }}$ quantile \\
\hline House owner & $-373.671^{* * *}$ & $-526.515^{* * *}$ & $-572.164 * * *$ & $-651.161 * * *$ & $-702.885 * * *$ & $-686.496 * * *$ & $-693.722 * * *$ \\
\hline Other capital income $>0$ & $87.313(*)$ & $103.337 *$ & 19.070 & -84.274 & $-173.868 * *$ & $-263.639 * * *$ & $-364.152 * *$ \\
\hline Farmer & -72.575 & 1.259 & 86.536 & $386.859 * *$ & $522.802 * * *$ & $728.040 * * *$ & $738.624 * * *$ \\
\hline Income compensation due to military service & -96.378 & 76.339 & 89.237 & 156.846 & 146.295 & 83.746 & -214.882 \\
\hline Income compensation due to illness/accident & -364.770 & -153.998 & -334.864 & -39.182 & 317.002 & 274.363 & 95.773 \\
\hline Community size 2 & 9.727 & 29.464 & 58.635 & 78.772 & 115.583 & 146.416 & 24.672 \\
\hline Community size 3 & -38.082 & 4.740 & 52.656 & -19.123 & 9.840 & -28.057 & -59.549 \\
\hline Community size 4 & -44.434 & -45.392 & -5.828 & -91.574 & -31.004 & -18.944 & 63.219 \\
\hline Community size 5 & $-402.252 *$ & -228.030 & -190.773 & -262.227 & -129.513 & -79.587 & 102.853 \\
\hline Community size 6 & -48.438 & 81.432 & 175.958 & 95.216 & 236.294 & 119.820 & 155.118 \\
\hline Community type 2 & $-132.222(*)$ & 25.499 & -47.903 & -110.107 & $-182.694^{*}$ & -109.111 & -155.895 \\
\hline Community type 3 & $-199.060(*)$ & -78.405 & -91.876 & -190.095 & -177.041 & $-267.295^{*}$ & $-339.454(*)$ \\
\hline Community type 4 & -269.178 & -112.541 & -55.444 & -101.727 & -96.284 & -72.154 & -212.175 \\
\hline Community type 5 & -121.890 & -4.312 & -15.885 & 15.445 & 50.736 & 20.724 & -66.917 \\
\hline Community type 6 & $-366.415^{*}$ & -133.568 & -111.503 & -77.569 & -141.665 & -195.486 & -287.454 \\
\hline Community type 7 & -118.736 & -26.597 & 78.156 & 93.060 & 39.558 & -206.223 & $-610.518(*)$ \\
\hline Community type 8 & -378.490 & -288.122 & -97.336 & 21.608 & 235.221 & 549.857 & 578.508 \\
\hline Constant & $21332.920 * *$ & $24848.200 * * *$ & $27072.370^{* * *}$ & 20916.910 & $22126.490\left(^{*}\right)$ & $20023.030\left(^{*}\right)$ & 10359.530 \\
\hline
\end{tabular}

